\title{
Legal-system Arbitrage and Parent-Subsidiary Capital Structures
}

\author{
Suman Banerjee \\ University of Wyoming \\ Thomas H. Noe* \\ Oxford University \& Balliol College
}

March 12, 2016

\begin{abstract}
This paper develops a new theory of the capital structure of parent-subsidiary organizations based on legal-system arbitrage: The capital structure of parent-subsidiary organizations is chosen to minimize the agency costs generated by selective renegotiation of claims written on the component legal entities. We show that optimal mixes of parentsubsidiary level financing minimize the default premia associated with the organization's overall financing package by equating the marginal enforceability of debt contracts written at the parent and subsidiary level. The enforceability of creditor claims depends not only on the legal regime but also on the size of the debt claims and the liquidation value of the firm's assets. Small claims written under a weak creditor rights regime may be more enforceable than large claims written under a regime with strong creditor protection. Thus, all optimal mixes involve some borrowing at the subsidiary level even if the subsidiary legal regime features weaker creditor protection than the parent regime. However, the mix between parent and subsidiary financing tilts toward the regime that features stronger creditor protection.
\end{abstract}

JEL Classification Codes: G15, G32, G33, G38, K4

Keywords: Conglomerate, Capital structure, Debt renegotiation, Multinational corporation, Parent-Subsidiary organization, Subsidiary financing

\footnotetext{
*Correspondence Information: +44(0)1865288933 \& thomas.noe@sbs.ox.ac.uk; +13077662155 \& sbanerj1@uwyo.edu. Thomas H. Noe gratefully acknowledges financial support for this research from the Oxford-Man Institute. Suman Banerjee gratefully acknowledges financial support for this research from the Ministry of Education, Singapore and SER Grant, the University of Wyoming. We would like to thank the session chair and the discussant for valuable comments during the Western Finance Association's annual meeting at Victoria, B.C., June 2010. We would also like to thank the session chair and the discussant for valuable comments during the Fourth Singapore International Conference on Finance at National University of Singapore, July 2010. We would like to thank the discussant for valuable comments at the AFBC Conference, December 2010. Also, we would like to thank Sugato Bhattacharyya, Joseph Cherian, Sudipto Dasgupta, David Hirshleifer, Ravi Jagannathan, Mark Humphery-Jenner, Ronald Masulis, Vikram Nanda, Paul Povel, Andre Shleifer and Jaime Zender for their insightful comments. The usual disclaimer applies. Special thanks are extended to the editor, Itay Goldstein, an associate editor and three anonymous reviewers for their patience and insightful comments on earlier drafts of this paper.
} 


\section{Introduction}

Parent-subsidiary organizations are corporate organizations consisting of a parent firm and its wholly-owned, legally distinct, subsidiary firms. The parent itself may be an operating concern or a holding company. Most conglomerates and multinational corporations are parent-subsidiary organizations. However, under our definition, a multinational or a conglomerate that operates as single legal entity articulated into divisions based on product line or geography would not be a parent-subsidiary organization. At the same time, a firm such as Xerox which is organized into legally distinct subsidiary firms operating in the same line of business (e.g., PARC in the case of Xerox) is a parent-subsidiary organization.

Because subsidiaries are legally distinct, each can follow its own capital structure policy. Moreover, when the parent-subsidiary organization is distressed, there exists no mechanism for aggregating the debt claims of creditors of the parent and subsidiary companies into a single formalized debt renegotiation process like Chapter 11 bankruptcy in the U.S. The parent's ownership claim on the subsidiary is simply an equity claim to dividend income, subordinated to the creditors of the subsidiary company. Per se, the parent company, like any other equity holder, has no liability for a subsidiary's debt obligations in excess of its equity stake. Sometimes parents guarantee subsidiary debt but such guarantees are not inherent in the parent-subsidiary relation and, in fact, subsidiaries frequently issue debt that is not guaranteed by other firms in the organization [Kolasinski, 2009].

In this paper we study the allocation of debt across the parent subsidiary organization from an optimal contracting perspective. We investigate how a parent-subsidiary organization allocates debt liabilities across its component legal entities. We center our analysis on the effect of legal regimes and the size of debt obligations on debt-claim enforcement. We show that parent-subsidiary organizations provide distressed firms significant flexibility: distressed parent-subsidiary organizations can select the component firms within the organization that will renegotiate their debt contracts in the event of financial distress. Ex post, this flexibility has value. However, ex post flexibility is priced ex ante. Thus, ex post optionality can sometimes lead to higher nominal interest rates. Because high interest rates induce additional agency costs by exacerbating the debt overhang problem, the parent-subsidiary organization has an ex ante incentive to design its parent-subsidiary capital structure to minimize its gains from these ex post renegotiation options.

We show that the parent-subsidiary organization's optimal choice of debt mix maximizes the enforceability of creditor claims. Enforceability clearly depends on the degree to which the legal regime favors creditors over debtors. However, the enforceability of a given creditor's claim also depends on the size of the claim. Large creditors are in a much weaker bargaining position than small creditors. When a creditor's claim is sufficiently large, the creditor knows that his concessions are required for a successful restructuring. Thus, if an agreement can be reached with the large creditor that maintains viability and provides the creditor more value than liquidation, the large creditor will make concessions in debt renegotiations. In contrast, a small creditor knows that his concessions are neither necessary nor sufficient for successful reorganization and thus will be much more obdurate. For this reason, the marginal enforceability of a claim, i.e., the effect of a small increase in claim's size on the creditor's distress payoff, is decreasing in the claim's size.

Because decreasing marginal enforceability holds regardless of whether creditor right varies between the parent and subsidiary legal regime, decreasing marginal enforceability leads to an interior optimum parentsubsidiary debt allocation even when the parent and subsidiary operate under the same legal regime -i.e., some debt is issued at both the parent and subsidiary level. The specific interior mix between parent and subsidiary borrowing does depend on creditor rights under the parent and subsidiary legal regimes. The stronger creditor rights under a given regime, holding claim size fixed, the greater the marginal enforceability 
of the debt contracts under that regime. Because, the optimal mix between parent and subsidiary finance maximizes total enforceability by equating marginal enforceability between parent and subsidiary debt, diminishing marginal enforceability implies that the firm will borrow more under the regime that features stronger creditor rights. However, the optimal parent/subsidiary debt mix will still be interior.

When cash flows in financial distress are uncertain, firms cannot exactly equate the marginal enforceability of claims for every realization of distress cash flows. In this case, the firm aims to equate expected marginal enforceability. Even though, given any fixed level of promised debt payments, claims written under the superior creditor rights regime are more enforceable, the endogenous determination of claim size leads to capital structure in which claims written under the superior creditor rights regime are more likely to be renegotiated. Renegotiation results in debt payments less than the face value of claims. Thus, at equilibrium capital structure, default risk is higher for claims written under the stronger creditor rights regime.

Because, increased enforceability implies higher payments to creditors for any given face value of debt, it increases the market value of debt relative to book value, i.e., it lowers default spreads. This analysis leads to some sharp empirical predictions:

i. The relative size of parent vs. subsidiary debt is positively related to the relative strength of the rights enjoyed by parent and subsidiary creditors.

ii. Debt contracts issued under the stronger legal regime have higher default risk.

iii. Using default premia or realized creditor concessions to measure creditor rights under a given legal regime, without controlling for firms' ability to endogenously allocate debt obligations across regimes, will always lead to spurious identification.

iv. Holding average level of creditor-rights constant across the parent-subsidiary organization, the average default spread faced by the organization will be decreasing in the difference between creditor rights in the parent and subsidiary legal regimes.

The first implication has been confirmed by empirical research (e.g., see Davydenko and Franks [2008] and Desai et al. [2004]). To our knowledge, the other implications have never been considered by corporate finance empiricists. In our opinion, these results are novel in the sense that they are not obvious outside the context of our agency/creditor rights framework. Moreover, because both the exogenous variables, e.g., creditor rights, going-concern vs. liquidation value and endogenous variables, e.g., parent-subsidiary debt levels and parent guarantees, are measurable and indeed have been measured, we propose that these implications are also testable. ${ }^{1}$

Although we believe that our specific application of contract theory to the parent-subsidiary relation is unique, our work is part of a more general stream of research devoted to analyzing the effects of intra-firm boundaries on firm behavior and performance.

There have been a number of papers that rationalize the formation of some types of subsidiaries. Multinational parent-subsidiary organizations have been rationalized by cross-border tax arbitrage (see e.g., Huizinga et al. [2008], Chowdhry and Nanda [1994], Chowdhry and Coval [1998], and John et al. [1991]). Undoubtedly tax arbitrage is sometimes an important practical consideration in the parent-subsidiary capital structure design. However, because subsidiaries are frequently formed within the same tax jurisdiction, it is not a complete explanation. The formation of subsidiaries by firms with significant exposure to distress caused by tort liability has been rationalized by LoPucki [1996], which argues that subsidiary formation is a way of shielding firm assets from tort claimants. The banking literature also considers parent-subsidiary banking organiza-

\footnotetext{
${ }^{1}$ Desai et al. [2004] and La Porta et al. [1999] proxy for creditor rights using legal origin and Fuentes and Maqueria [1999] refine the measurement of creditor rights using other criteria.
} 
tions but from the perspective of market imperfections unique to banking (e.g., deposit insurance). For example, see Kahn and Winton [2002]. Bebchuk [1999] considers the social optimality of parent-subsidiary organization structures. We take the parent-subsidiary structure as given and, in contrast to Bebchuk, analyze its implications for corporate capital structure policy.

However, research on intra-firm boundaries has primarily focused on conglomerate firms rather than parent subsidiary organizations. ${ }^{2}$ In practice, the overlap between conglomerates and parent-subsidiary organizations is large. However, being a conglomerate is neither a necessary nor a sufficient condition for being a parent-subsidiary organization. The pyramidal structure is another form of intra-corporate structure that has been the subject of research. ${ }^{3}$ In pyramidal structures, in contrast to parent-subsidiary organizations, subsidiaries hold ownership stakes in each other and outsiders frequently own a portion of the subsidiary firms. Thus, the incentive problems in such firms are fundamentally different from the ones we model.

Because our model is a fairly standard contract theory model, we are deeply indebted to the literature on contract theory. Because of the enormous size of this literature and limited length of this article we freely acknowledge our debt but cannot hope to repay it. ${ }^{4}$ In many ways the results of the model are reminiscent of the capital structure "balancing models" in that these models predict balancing of the firm's overall debt level while our model predicts balancing between parent and subsidiary debt. ${ }^{5}$ However, the drivers of our analysis - moral hazard and commitment - are orthogonal to the drivers of balancing models - bankruptcy costs and taxes.

\section{Model preliminaries}

We develop a simple model in which an owner, called the "shareholder," requires outside financing to invest in a positive NPV project. Outside financing takes the form of debt. Because debt is risky, debt financing generates a classic debt overhang problem - part of the gains from the efforts of the shareholder is captured by creditors and this partial capture reduces the shareholder's incentive to exert effort. The only twists in the model are that (a) the shareholder owns two legally distinct entities, a parent and a subsidiary firm, and can borrow by issuing claims against either entity and (b) in the event of financial distress the shareholder can attempt to renegotiate the terms of the debt claims issued.

\subsection{Overview}

We assume that the risk-free rate of interest is zero; all agents are risk neutral; capital markets are competitive. In this context, consider an investment project. The right to undertake the project is owned by a subsidiary, $S$. A parent firm $P$ owns all of the subsidiary's equity. The capital structure and investment policies of both parent and subsidiary are determined by the parent firm's shareholders, who act to maximize their own welfare. Because the owners of the parent act as if they are a single agent, we will often refer to this group simply as the "shareholder." We will refer to the parent-subsidiary organization as the "firm."

All cash flows of the firm come from the subsidiary's project and are realized at date $2{ }^{6}$ Financing the

\footnotetext{
${ }^{2}$ See, for example, Goel et al. [2004], Kahn and Winton [2002], Maksimovic and Phillips [2002], Ozbas [2005], Scharfstein [1998] and Stumpp et al. [2003].

${ }^{3}$ See, for example, Almeida and Wolfenzon [2006] and Lee [2010].

${ }^{4}$ For an extensive review of this literature, see Hart and Holmstrom [1987].

${ }^{5}$ See Leland [1994] for an example of a balancing model of capital structure.

${ }^{6}$ We relax this assumption in Appendix B of the working paper version of this manuscript and show that our results are robust to changes in this assumption.
} 
project requires a one-time investment of $I$ dollars. Since there are no internal funds or assets in place, all project financing, of necessity, is external. Financial claims in our model are debt claims on cash flows. Funds can be raised at the parent and/or the subsidiary level. The focus of the model is on finding the optimal debt mix between these two sources of financing rather than the firm's total debt level. We assume that creditors of the subsidiary are distinct from creditors of the parent. In the event of financial distress, both subsidiary creditors and parent creditors act as a single agent maximizing the total payoffs from their respective claims. Hence, we lump together the creditors of the subsidiary and simply refer to them as "creditor $S$ " or the "subsidiary creditor." Similarly, we refer to the creditors of the parent as "creditor $P$ " or the "parent creditor." The shareholder is required to raise funds to finance the investment project. Funds are raised by issuing zero-coupon bonds to the subsidiary and parent creditors. We denote the face value (or promised payment) of all bonds issued to the subsidiary creditor by $k_{S}$ and call it "subsidiary debt." Similarly, we denote the face value of all bonds issued to the parent creditor by $k_{P}$ and call it "parent debt." The shareholder chooses $k_{S}$ and $k_{P}$. We use $k$ to denote the total face value of all bonds issued; i.e., $k=k_{S}+k_{P}$. We also call $k$ the "total promised payment."

Terminal cash flows are distributed using the absolute priority rule based on the debt contract in place at the time of distribution. The parent's cash flow comes from a dividend paid by the subsidiary to the parent, which is equal to the residual cash flows after satisfying the subsidiary creditor. Dividends from the subsidiary is then divided between parent creditor and the shareholder, again based on absolute priority. ${ }^{7}$ The sequence of actions is as follows:

- Date -2: The shareholder picks a capital structure. This capital structure consists of zero-coupon bonds issued to creditor $S$, and/or to creditor $P$, and written on the cash flows of the respective entities. The capital structure, i.e., choice of $k_{S}$ and $k_{P}$ must be such that the firm is able to raise $I$ dollars required for the new investment.

- Date -1: The shareholder picks an unverifiable ex ante effort level $e$. The effort level affects the probability that financial state is nondistressed as opposed to distressed. This ex ante effort level has a non-pecuniary disutility.

- Date 0: The financial condition of the firm is revealed. The firm's financial condition can either be nondistressed or distressed. Financial condition is observable by all parties, but not verifiable and thus not contractible. If the financial condition is nondistressed, continued operation will not require further effort by the shareholder and cash flows will equal $x^{\mathrm{ND}}$. If the condition is distressed, continued operation as a going-concern will require further effort from the shareholder. Also, the shareholder will have an opportunity to renegotiate debt contracts with both creditors.

- Date 1: The shareholder makes ex post effort decision when the firm is in the distressed condition. The shareholder's ex post effort cannot be observed by the creditors. Thus, it is not possible to contract on ex post effort. If effort is provided, the value of the distressed firm is going-concern value, $x^{\mathrm{D}}$; if effort is not provided the value of the distressed firm is liquidation value, $\ell$. The non-pecuniary cost of ex post effort to the shareholder is $c$.

- Date 2: Cash flows are realized and divided between the shareholder and the creditors based on (possibly renegotiated) debt contracts.

The timeline for the model is presented in Figure 1.

\footnotetext{
${ }^{7}$ In Appendix $\mathrm{C}$ of the working paper version of this manuscript, we show that permitting the parent to hold senior claims does not produce solutions that results in higher payoffs to the shareholder. Moreover, given the doctrine of "equitable subordination," the enforceability of parent senior claims in the event of liquidation is problematic.
} 
Figure 1: Timeline.

\begin{tabular}{lllll}
\multicolumn{1}{c}{ date -2} & date -1 & date 0 & date 1 & date 2 \\
\hline $\begin{array}{l}\text { Financing is } \\
\text { obtained and } \\
\text { capital structure }\end{array}$ & $\begin{array}{l}\text { Shareholder makes } \\
\text { an ex ante } \\
\text { effort decision }\end{array}$ & $\begin{array}{l}\text { Signal regarding } \\
\text { financial condition } \\
\text { is received and debt } \\
\text { can be renegotiated }\end{array}$ & $\begin{array}{l}\text { Shareholder makes } \\
\text { an ex post } \\
\text { effort decision }\end{array}$ & $\begin{array}{l}\text { Cash flows } \\
\text { are realized }\end{array}$ \\
\end{tabular}

\section{The shareholder's ex ante incentives}

Except for the negotiations between the shareholder and creditors at date 0, the model is relatively simple to analyze. For this reason, in this section, we develop our analysis taking the results of date 0 bargaining as given. We show that the possibility of renegotiating debt obligations makes the debt overhang problem worse and that, for a wide variety of debt renegotiation mechanism, the shareholder's optimal choice of debt mix will be designed to minimize his own gain from the ex post renegotiation option. In Section 4.1, we will consider the date 0 bargaining game in detail.

\subsection{Date -2 investment and capital structure problem.}

We assume that

$$
\ell<x^{\mathrm{D}}-c<k<x^{\mathrm{ND}} .
$$

Thus, cash flows in the distressed state, $x^{\mathrm{D}}$, net of ex post effort cost, $c$, are less than the total promised payments but exceed the liquidation value. Cash flows in the nondistressed state exceed total promised payments. Dividends received by the shareholder depends not only on the total promised payments, $k_{S}$ and $k_{P}$, but also on the renegotiated debt payments. However, promised debt payments will determine the negotiated debt payments at date 0 . We note this dependence by representing the debt payments received by the two creditor groups in the nondistressed state with $C^{\mathrm{ND}}\left(k_{S}, k_{P}\right)$ and in the distressed state by $C^{D}\left(k_{S}, k_{P}\right)$. These payoffs are treated as exogenous until we endogenously determine them in Section 4.1.

We also denote the likelihood of nondistressed state by $\operatorname{Prob}(\mathrm{ND})$ and the likelihood of distressed state by $\operatorname{Prob}(\mathrm{D})=1-\operatorname{Prob}(\mathrm{ND})$. In order for the creditors to be willing to fund the project, it must be the case that the expected value of their claim at least equals their investment, $I$; i.e., it must be the case that

$$
\operatorname{Prob}(\mathrm{ND}) C^{\mathrm{ND}}\left(k_{S}, k_{P}\right)+\operatorname{Prob}(\mathrm{D}) C^{D}\left(k_{S}, k_{P}\right) \geq I \text {. }
$$

Note that if condition (2) is satisfied, it is always possible to ensure that the participation constraint of each of the creditors, $S$ and $P$, is satisfied. The shareholder only needs to raise funds from each creditor in an amount less than or equal to the value of that creditor's individual claim. This is always possible if the total value of claims at least equals the required investment. In contrast, if condition (2) is not satisfied, then total claim value is less than $I$. Therefore, it is not possible to offer both creditors claims whose value is at least equal to funds raised. Thus, condition (2) is necessary and sufficient for creditor participation.

We also assume that $k<x^{\mathrm{ND}}$. The assumption that $k<x^{\mathrm{ND}}$ is without loss of generality because the shareholder cannot possibly satisfy promised debt claims that exceed the highest possible cash flow. Because 
in the nondistressed state, ex post effort is not required to produce the cash flow of $x^{\mathrm{ND}} \geq k$, creditors have no incentive to accept renegotiation offers from the shareholder. At the same time, since the shareholder always has the option of affirming the debt contract and paying the face value of debt to the creditors, the total payments to creditors can never exceed total promised payments. Thus, in the nondistressed state, the shareholder's actual payments to creditors equal the total promised payments, $k=k_{S}+k_{P}$, i.e., $C^{\mathrm{ND}}\left(k_{S}, k_{P}\right)=k_{S}+k_{P}=k$. Hence, we can rewrite condition (2) as follows:

$$
\operatorname{Prob}(\mathrm{ND}) k+\operatorname{Prob}(\mathrm{D}) C^{D}\left(k_{S}, k_{P}\right) \geq I
$$

Because the shareholder always satisfies creditors in the nondistressed state, the shareholder's payoff in the nondistressed state, $\Pi_{\mathrm{ND}}$, is given by

$$
\Pi_{\mathrm{ND}}=x^{\mathrm{ND}}-k
$$

By assumption (1), $x^{\mathrm{D}}-c<k$. Moreover, equilibrium debt payments never exceed total promised payments, i.e., $C^{D}\left(k_{S}, k_{P}\right) \leq k$. Thus, in order for (3) to be satisfied, $k$ must exceed $x^{\mathrm{D}}-c$. Because, $k>x^{\mathrm{D}}-c$, and because the shareholder will not exert ex post effort unless they receive a payment of at least $c$, debt must be renegotiated in the distressed state in order for liquidation to be avoided. Because $\ell<x^{\mathrm{D}}-c$, avoiding liquidation is efficient. Thus, debt will be renegotiated in the distressed state. Let $S^{D}\left(k_{S}, k_{P}\right)$ represent the shortfall in debt payments in the distressed state, i.e., $S^{D}\left(k_{S}, k_{P}\right)=k-C^{D}\left(k_{S}, k_{P}\right)$. Using these observations, we can write the payoff to the shareholder in the distressed state as

$$
\Pi_{\mathrm{D}}=\left(x^{\mathrm{D}}-c\right)-\left(k-S^{D}\left(k_{S}, k_{P}\right)\right) .
$$

\subsection{Effort and the date -1 ex ante effort decision}

We assume that the shareholder picks an unverifiable/unobservable ex ante effort level $e$ at date -1 after the capital structure has been fixed, and that this effort level determines the probability that the financial state is nondistressed as opposed to distressed. Specifically, we assume that the probability that the firm is financially nondistressed equals the shareholder's effort level, i.e., $\operatorname{Prob}(\mathrm{ND})=e$ and $\operatorname{Prob}(\mathrm{D})=1-e$. Thus, the probability of the nondistressed state is increasing in ex ante effort. We also posit a continuum of ex ante effort levels, $e \in[0,1]$. This ex ante effort level has a non-pecuniary disutility of $(\gamma / 2) e^{2}$ to the shareholder. Moreover, we assume that the effort cost parameter, $\gamma$, satisfies the following restriction:

$$
\gamma>x^{\mathrm{ND}}-\left(x^{\mathrm{D}}-c\right)
$$

As will become apparent in the sequel, condition (6) ensures that the first-best effort level is interior. Then, for a fixed level of effort, $e$, the payoff to the shareholder is given by

$$
\Pi=e \Pi_{\mathrm{ND}}+(1-e) \Pi_{\mathrm{D}}-\frac{\gamma}{2} e^{2}=e\left(x^{\mathrm{ND}}-k\right)+(1-e)\left(\left(x^{\mathrm{D}}-c\right)-\left(k-S^{D}\left(k_{S}, k_{P}\right)\right)\right)-\frac{\gamma}{2} e^{2} .
$$

Using our assumptions regarding the relation between ex ante effort and the probability of distress, the participation constraint for the creditor, given by Expression (3), can be expressed as

$$
\mathrm{CP}: \quad e k+(1-e)\left(k-S^{D}\left(k_{S}, k_{P}\right)\right) \geq I
$$

Next consider the shareholder's date -1 effort decision. The shareholder will chose an effort level $e \in[0,1]$ to maximize $\Pi$ as stated in Equation (7). At date -1 the capital structure has already been fixed, which 
fixes the shareholder's payoffs conditional on distressed or nondistressed state. Thus, at date -1, the shortfall in the distressed state is fixed and is unaffected by the shareholder's effort choice. Shareholder's effort choice only impacts the likelihood of occurring of the distressed versus nondistressed state. Differentiating the shareholder's payoff given by Equation (7) with respect to ex ante effort, $e$, and solving the first-order condition, yields the following expression for optimal effort choice:

$$
\text { IC: } \quad e=\frac{x^{\mathrm{ND}}-\left(x^{\mathrm{D}}-c\right)-S^{D}\left(k_{S}, k_{P}\right)}{\gamma} .
$$

Assumption (6) ensures that the right-hand side of Equation (9) is always less than 1 and thus the constraint, $e \leq 1$ is always strictly satisfied. It is possible for $x^{\mathrm{ND}}-\left(x^{\mathrm{D}}-c\right)-S^{D}\left(k_{S}, k_{P}\right) \leq 0$, in which case optimal effort equals 0 . However, when optimal effort equals zero, the creditor participation constraint (8) is violated and hence the firm cannot obtain financing. Thus,

$$
x^{\mathrm{ND}}-\left(x^{\mathrm{D}}-c\right)-S^{D}\left(k_{S}, k_{P}\right)>0
$$

is a necessary condition that must be satisfied by any feasible solution to the firm's financing problem. ${ }^{8}$ Equation (9) imposes an incentive compatibility condition on effort. If effort were observable and selected at date -2, the creditor participation constraint would force the shareholder to internalize the effect of effort on creditor payoffs. In which case, the shareholder would select the first-best level of effort, $e^{\mathrm{fb}}$ which maximizes

$$
e x^{\mathrm{ND}}+(1-e)\left(x^{\mathrm{D}}-c\right)-\frac{\gamma}{2} e^{2}
$$

Thus, the shareholder would pick

$$
e^{\mathrm{fb}}=\frac{x^{\mathrm{ND}}-\left(x^{\mathrm{D}}-c\right)}{\gamma} .
$$

As can be seen by comparing (9) and (12), the shortfall always lowers effort below the first-best level. The larger the shortfall the larger the distortion of the shareholder's effort incentives.

\subsection{The shareholder's ex ante capital structure problem}

At date -2 , the shareholder and the creditors will anticipate the incentive compatible level of date -1 effort induced by the capital structure. Thus, we can collapse the date -1 effort problem and the date -2 capital structure problem into a single problem. We will call this the ex ante problem, where the shareholder selects effort and capital structure $\left(e, k_{S}, k_{P}\right)$ to maximize $\Pi$ subject to the creditor participation constraint, given by Expression (8), and the date -1 effort incentive compatibility constraint, given by Equation (9). As one can see by inspecting Expressions (8) and (9), reducing the distressed state shortfall, $S^{D}$, increases the shareholder's ex ante effort incentives. For any fixed level of total promised debt payments, $k$, the shortfall is reduced by increasing payments to creditors in the distress state, $C^{D}\left(k_{S}, k_{P}\right)$. Thus, increasing payments to creditors in the distressed state increases the shareholder's effort incentives. Because, shareholder effort is below first-best effort, the increase in effort incentives raises total firm value, the sum of creditor and shareholder value. If the shareholder is able to capture the total value gain due to reduced shortfall, then optimal ex ante capital structures will minimize shortfalls in the distressed state. One might expect that, in a competitive financial market in which creditors are willing to finance at any terms that ensure they break even, any reasonable renegotiation regime would permit such gain transfers and thus optimal ex ante capital

\footnotetext{
${ }^{8}$ Condition (10) is not a sufficient condition for the existence of a feasible solution to the firm's financing problem. However, our aim in this paper is to characterize feasible solutions rather then derive conditions for their existence. Thus, the insufficiency of condition (10) for establishing the existence of a solution to the firm's financing problem is not relevant to the subsequent analysis.
} 
structure policies will minimize shortfalls in the distressed state. We formalize this intuition as follows: First, we specify the properties of a reasonable $C^{D}$ function.

Definition 1. The function $C^{D}$ (which relates promised creditor payments to actual creditor payments in the distressed state) is regular if it has the following properties:

I. $C^{D}\left(k_{S}, k_{P}\right) \leq k_{S}+k_{P}=k$,

II. $C^{D}$ is continuous,

III. $S^{D}\left(\alpha k_{S}, \alpha k_{P}\right)=\alpha\left(k_{S}+k_{P}\right)-C^{D}\left(\alpha k_{S}, \alpha k_{P}\right)$ is nondecreasing in $\alpha \in[0,1]$.

Regularity appears to be a very minimal restriction on the relation between actual payments in distress and nominal debt payments. As long as the shareholder has the option of honoring debt contracts, Property I of Definition 1 will be satisfied. Property II will hold so long as small changes in promised payments do not trigger large jumps in actual payments. Property III simply requires that proportionally decreasing the face value of all debt claims does not increase the total shortfall faced by all creditors. If $C^{D}$ is regular, the gain in total value from reducing the shortfall can be translated into increased shareholder payoffs. In which case, optimal ex ante policies always maximize actual creditor payments in the distressed state for a given level of total promised payments. This result is stated in the following proposition. In Section 4.1.5 we will show that our specific renegotiation mechanism generates a $C^{D}$ which is regular.

Proposition 1. Suppose that $C^{D}$ is regular and $\left(e^{*}, k_{S}^{*}, k_{P}^{*}\right)$ is an ex ante optimal policy, then $\left(e^{*}, k_{S}^{*}, k_{P}^{*}\right)$ maximizes the payments to creditors in the distressed state over all policies featuring the same total debt payments, $k^{*}=k_{S}^{*}+k_{P}^{*}$. Moreover, any alternative parent-subsidiary debt mix $\left(k_{S}, k_{P}\right)$ which produces the same total promised payments as $k^{*}$ and the same total payments to creditors in the distressed state, $C^{D}\left(k_{S}, k_{P}\right)$, is also an optimal policy, i.e., if $\left(e^{*}, k_{S}^{*}, k_{P}^{*}\right)$ is an ex ante optimal policy and $k^{*}=k_{S}^{*}+k_{P}^{*}$, then

(i) $C^{D}\left(k_{S}^{*}, k_{P}^{*}\right)=\max _{k_{S}+k_{P}=k^{*}} C^{D}\left(k_{S}, k_{P}\right)$, and

(ii) if $C^{D}\left(k_{S}, k_{P}\right)=\max _{k_{S}+k_{P}=k^{*}} C^{D}\left(k_{S}, k_{P}\right)$, then $\left(e^{*}, k_{S}, k_{P}\right)$ is an ex ante optimal policy.

Proof. See the Appendix.

Proposition 1 shows that, holding constant total promised payments to creditors, the optimal mix of parent/subsidiary only affects the ex ante payoff to the shareholder through its effect on the total payments to creditors in the distressed state. Moreover, the ex ante payoff of the shareholder is increasing in total payments to creditors in the distressed state. Thus, the basic question which we address in this paperwhat is the optimal mix between subsidiary and parent debt for a given level of total borrowing? - can be answered without solving for the optimal total promised level of debt. Instead, we only need to identify capital structure mixes that, for a given level of total borrowing, maximize total payments to creditor in the distressed state.

\section{Debt renegotiation}

In this section, we model debt renegotiations in the distressed state. The outcome of these debt renegotiations will determine the relation between promised debt payments and the actual debt payments made by the shareholder in the distressed state. We show that the shareholder's ability to issue claims on two legally distinct entities, the parent and subsidiary, generates ex post renegotiation options. After obtaining financing, 
the shareholder will attempt to use these options to minimize total payments to creditors in the distressed state.

\subsection{The date 0 ex post bargaining problem}

Thus far we have not determined the function $C^{D}$ that relates promised debt payments to actual debt payments in the distressed state. We now turn to this task. $C^{D}$ will be the product of ex post bargaining between the shareholder and the creditors. The key result in this section is that the shareholder's ex post and ex ante incentives are diametrically opposed: Ex ante, the shareholder factors in the adverse effect of the debt payment shortfall on his ex ante effort incentives. Whereas ex post, once ex ante effort has been provided and the project has been funded, this consideration is no longer relevant. Total cash flows in the distressed state conditioned on successful reorganization are fixed and, since all cash flows are divided between the shareholder and the creditors, the shareholder aims to minimize actual debt payments. The strategy the shareholder uses will depend on the specifics of the payoffs to the parties, the structure of the bargaining game, and the strength of creditor rights.

\subsubsection{Payoffs from the final cash flow division}

Let $k_{S}^{2}$ represent the face value of the debt issued to creditor $S$ at date 2 , the date at which final cash flows are divided. This face value might be either the initial face value or some lower renegotiated value. Similarly, let $k_{P}^{2}$ represent the face value at date 2 of debt issued to creditor $P$. Thus, in distress the contracted payments to creditor $S$, creditor $P$, and the shareholder, are given as follows: The payoff to creditor $S$ is

$$
\min \left[z, k_{S}^{2}\right]
$$

where $z$ represents cash flow either from liquidation $(\ell)$ or operation $\left(x^{\mathrm{D}}\right)$. The residual value after satisfying the subsidiary creditors, $z-\min \left[z, k_{S}^{2}\right]$, is owned by the subsidiary and paid out to the parent firm which owns $100 \%$ of the subsidiary's equity. Because the parent has no assets other than the cash flow from the subsidiary's dividend, the payoff to creditor $P$ is

$$
\min \left[z-\min \left[z, k_{S}^{2}\right], k_{P}^{2}\right]=\min \left[\left(z-k_{S}^{2}\right)^{+}, k_{P}^{2}\right]
$$

where $\left(z-k_{S}^{2}\right)^{+}=\max \left[0, z-k_{S}^{2}\right]$. If the firm is not liquidated, the payoff to the shareholder is the residual payment, after both creditor $S$ and creditor $P$ are satisfied; that is,

$$
z-\min \left[z, k_{S}^{2}\right]-\min \left[\left(z-k_{S}^{2}\right)^{+}, k_{P}^{2}\right]
$$

If the firm is liquidated, the payoff to the shareholder is 0 . To simplify notation, we use $\underline{\pi}_{S}$ and $\underline{\pi}_{P}$ to represent the payoffs to creditor $S$ and creditor $P$ if the state is distressed and liquidation occurs:

$$
\begin{aligned}
& \underline{\pi}_{S}=\min \left[k_{S}^{2}, \ell\right] \\
& \underline{\pi}_{P}=\ell-\min \left[k_{S}^{2}, \ell\right]=\ell-\underline{\pi}_{S} .
\end{aligned}
$$




\subsubsection{Debt renegotiation strategies}

We assume that bargaining is sequential with the shareholder approaching each creditor individually. ${ }^{9}$ Bargaining in each of the negotiations is structured in a standard Hart-Moore framework: After approaching a creditor, the shareholder can either repudiate or affirm the outstanding debt contract of that creditor. ${ }^{10}$ If the shareholder affirms the debt contract, the initial face value of the debt stands. If the shareholder repudiates the contract, the shareholder bargains with the creditor. When the shareholder repudiates, the original debt contract is voided and the creditor acquires the right to enforce liquidation. Liquidation results in the division of the firm's assets based on absolute priority between the creditors.

Bargaining in the event of repudiation proceeds as follows: First, the shareholder proposes a new claim structure to the creditor. If the creditor accepts this offer, the claim structure is changed accordingly. If the creditor rejects the initial offer, then with probability $1-\rho$ the shareholder's option to apply ex post effort is lost. We call this event "dissipation." If dissipation occurs, creditors have no incentive to negotiate with the shareholder and it is a dominant strategy for the creditors to enforce liquidation. We refer to this case as the case where "negotiations break down" or where "liquidation is triggered." When liquidation is triggered, the creditors receive their liquidation payoffs $\underline{\pi}_{j}$ where $j=S$ or $P$. If negotiations do not break down, which occurs with probability $\rho$, the creditor being negotiated with makes a final offer. The rejection of this offer triggers liquidation with probability 1 . If the final offer is accepted, then the final offer becomes the new face value of debt. ${ }^{11}$

Assuming that the negotiation with the first creditor does not result in liquidation, the shareholder turns to the next creditor. Negotiations with the second creditor follow the same schema as negotiations with the first creditor. Once negotiations cease, the game proceeds as specified in the timeline presented in Section 2.1. The cash flow to the shareholder is positive only if both creditors' (possibly renegotiated) claims are satisfied. The shareholder's payoff in a renegotiation that ensures ex post effort is the total cash flow less the (possibly renegotiated) claims. To ensure effort, shareholder's payoff must be at least equal to the cost of effort, $c$.

Given our assumption that $x^{\mathrm{D}}-c>\ell$, there exists a renegotiation offer which at least one creditor will prefer to liquidation. Given that $x^{\mathrm{D}}<k$, at least one claim must be renegotiated to avoid liquidation. Thus, the shareholder will always attempt to renegotiate at least one claim. This leaves the shareholder with three viable renegotiation strategies: Repudiate and renegotiate both claims; affirm creditor $S$ 's claim and repudiate and renegotiate creditor $P$ 's claim; affirm creditor $P$ 's claim and repudiate and renegotiate creditor $S$ 's claim.

Note that a shareholder will never attempt a renegotiation strategy that involves making an offer to the creditor that will be rejected. Such an offer would provide the shareholder with a zero payoff. As we will see in Section 4.1.3, the strategy of renegotiating both claims by making offers that are acceptable to both creditors is always feasible and provides the shareholder with a positive payoff. Therefore, shareholder strategies leading to negotiation failure and thus liquidation are never optimal. Also, the shareholder prefers the smallest possible debt payment that is acceptable to the creditors. This debt payment to each creditor must equal the expected payoff to the creditor if he rejects the shareholder's initial offer, taking into consideration the risk of dissipation faced by the creditor before the creditor can make a final offer extracting all the

\footnotetext{
${ }^{9}$ Our results are robust to the variations in the bargaining structure. See the working paper version of this paper, especially Appendix D.

${ }^{10}$ Our results are robust to the assumption that renegotiation requires repudiation of the debt contract. See the working paper version of this paper, especially Appendix E.

${ }^{11}$ Our bargaining game is thus a two-move version of the standard Osborne and Rubinstein [1990] bargaining game.
} 
surplus value.

\subsubsection{Negotiating with both creditors}

Because we assume that the shareholder negotiates sequentially with both creditors, either the shareholder first negotiates with creditor $S$ and then negotiates with creditor $P$, or the shareholder first negotiates with creditor $P$ and then negotiates with creditor $S$. At the end of this section, we will show that the total debt payment in the distressed state is unaffected by the order of negotiation. Hence, without loss of generality, we assume that the shareholder negotiates first with creditor $S$ and then with creditor $P$. Also, because there are no debt renegotiations in the nondistressed state, we will call the payments negotiated in distressed state simply the "debt payments."

Because the shareholder negotiates first with creditor $S$, creditor $S$ can obtain $x^{\mathrm{D}}-c-\underline{\pi}_{P}$ if he rejects the shareholder's initial offer and is able to make a final counteroffer for the entire surplus. Creditor $S$ is able to make this counteroffer with probability $\rho_{S}$. Otherwise, rejection triggers liquidation. Under liquidation, creditor $S$ receives only liquidation value, $\underline{\pi}_{S}$. Therefore, the shareholder offers creditor $S$ a renegotiated claim with value equal to $S$ 's expected value from rejecting shareholder's offer and thus, creditor $S$ accepts this offer. Hence, the renegotiated debt payment to creditor $S$, is given by

$$
k_{S}^{r}=\rho_{S}\left(x^{\mathrm{D}}-c-\underline{\pi}_{P}\right)+\left(1-\rho_{S}\right) \underline{\pi}_{S} .
$$

Now consider the offer to creditor $P$. If liquidation does not occur, the final offer by the second creditor must leave enough funds both for the shareholder to receive a payoff of $c$ and for the first creditor's renegotiated claim to be satisfied. If liquidation does occur, the second creditor will receive his share of liquidation value. Thus, using the same logic as used for Equation (18), the shareholder's offer to the second creditor will equal

$$
k_{P}^{r}=\rho_{P}\left(x^{\mathrm{D}}-c-k_{S}^{r}\right)+\left(1-\rho_{P}\right) \underline{\pi}_{P} .
$$

Simplifying this expression, using the fact that $\underline{\pi}_{S}+\underline{\pi}_{P}=\ell$ yields the total debt payment, $k_{S}^{r}+k_{S}^{r}$, to the creditors. This total debt payment, represented by $C$, is given by

$$
C\left(k_{S}, k_{P} \mid \mathrm{Both}\right)=\left(1-\eta\left(\rho_{S}, \rho_{P}\right)\right)\left(x^{\mathrm{D}}-c\right)+\eta\left(\rho_{S}, \rho_{P}\right) \ell,
$$

where $\eta\left(\rho_{S}, \rho_{P}\right)=\left(1-\rho_{S}\right)\left(1-\rho_{P}\right)$. Note that because $\eta \in(0,1)$ and $\ell<x^{\mathrm{D}}-c$, the total debt payment is always less than $x^{\mathrm{D}}-c$.

Reversing the order of negotiation would simply flip the order of $\rho_{S}$ and $\rho_{P}$ in Expression (20). But the right hand side of Expression (20) is a symmetric function of $\rho_{S}$ and $\rho_{P}$. Thus, flipping the order of negotiations would have no effect on the total debt payments made to the two creditors. This result verifies our assertion that the assumed order of renegotiation is made without loss of generality.

\subsubsection{Negotiating with only one creditor}

In this section, we consider single creditor negotiation strategies. We will call the creditor whose claim is repudiated the "repudiated creditor" and the creditor whose claim is affirmed the "affirmed creditor." We subscript the variables associated with the affirmed creditor with "Aff" and subscript the variables associated with the repudiated creditor with "Rep." If $x^{\mathrm{D}}-c-k_{\mathrm{Aff}}<\underline{\pi}_{\text {Rep }}$, then a repudiated creditor can attain a 
higher payoff from liquidation than from making a final offer to the shareholder which satisfies the affirmed creditor and provides the shareholder with $c$. In this case, successful renegotiation with the repudiated creditor is infeasible. Otherwise, the repudiated creditor can make a final offer which, if accepted, produces a higher payoff to that creditor than liquidation. The final offer by a repudiated creditor must leave the shareholder with $c$, and the affirmed creditor with $k_{\text {Aff. }}$ Thus, the largest payment the repudiated creditor can obtain from a final offer is $x^{\mathrm{D}}-c-k_{\mathrm{Aff}}$. If the repudiated creditor rejects the shareholder's initial offer, he expects to avoid dissipation with probability $\rho_{\text {Rep }}$ and receives liquidation value with probability $1-\rho_{\text {Rep }}$. Thus, the shareholder's initial offer to the repudiated creditor equals the repudiated creditor's expected payoff from rejecting the shareholder's offer, that is,

$$
k_{\text {Rep }}^{r}=\rho_{\text {Rep }}\left(x^{\mathrm{D}}-k_{\mathrm{Aff}}-c\right)+\left(1-\rho_{\mathrm{Rep}}\right) \underline{\pi}_{\mathrm{Rep}} .
$$

This offer will be accepted by the repudiated creditor. Total payments to creditors equal

$$
k_{\text {Rep }}^{r}+k_{\text {Aff }}=\rho_{\text {Rep }}\left(x^{\mathrm{D}}-c\right)+\left(1-\rho_{\mathrm{Rep}}\right)\left(k_{\mathrm{Aff}}+\underline{\pi}_{\mathrm{Rep}}\right) .
$$

Expression (22) is valid only when renegotiation is feasible. However, we assert that when renegotiation is not feasible, the payment to creditors produced by Expression (22) is always higher than the value produced by renegotiating both contracts (specified in Equation (20)). Because the payment made by the shareholder is the minimum across the three negotiation strategies, we can safely ignore the feasibility condition when determining the equilibrium shareholder payment to creditors. To verify our assertion, first note that Expression (22) is increasing in $k_{\text {Aff }}$. Next, note that if renegotiation is infeasible, then $k_{\text {Aff }}>x^{\mathrm{D}}-c-\underline{\pi}_{\text {Rep }}$. Thus, when renegotiation is infeasible, the total debt payment specified by Expression (22) is bounded below by the expression's value when

$$
k_{\mathrm{Aff}}=x^{\mathrm{D}}-c-\underline{\pi}_{\mathrm{Rep}} .
$$

If we substitute Equation (23) into Expression (22) we see that the total debt payment equals $x^{\mathrm{D}}-c$, which strictly exceeds the payment under renegotiation of both contracts, given by Equation (20). Specializing Expression (21) for the two cases, parent-only and subsidiary-only renegotiation, we see that the total debt payment from negotiating only with the parent creditor is

$$
C\left(k_{S}, k_{P} \mid P \text { only }\right)=\left(1-\rho_{P}\right) k_{S}+\rho_{P}\left(x^{\mathrm{D}}-c\right)+\left(1-\rho_{P}\right)\left(\ell-\underline{\pi}_{S}\right) .
$$

And the total debt payment from negotiating only with the subsidiary creditor is

$$
C\left(k_{S}, k_{P} \mid S \text { only }\right)=\left(1-\rho_{S}\right) k_{P}+\rho_{S}\left(x^{\mathrm{D}}-c\right)+\left(1-\rho_{S}\right) \underline{\pi}_{S} .
$$

\subsubsection{Minimum total debt payment}

Combining the equations for the three renegotiation strategies given by Equations (20), (24), and (25), and noting that the shareholder chooses the strategy producing the smallest payment, yields the optimal ex post debt payment to creditors in the distressed state, $C^{D}$ :

$$
C^{D}\left(k_{S}, k_{P}\right)=\min \left[\begin{array}{l}
\left(1-\eta\left(\rho_{S}, \rho_{P}\right)\right)\left(x^{\mathrm{D}}-c\right)+\eta\left(\rho_{S}, \rho_{P}\right) \ell \\
\left(1-\rho_{P}\right) k_{S}+\rho_{P}\left(x^{\mathrm{D}}-c\right)+\left(1-\rho_{P}\right)\left(\ell-\underline{\pi}_{S}\right), \\
\left(1-\rho_{S}\right) k_{P}+\rho_{S}\left(x^{\mathrm{D}}-c\right)+\left(1-\rho_{S}\right) \underline{\pi}_{S}
\end{array}\right]
$$


where $\eta\left(\rho_{S}, \rho_{P}\right)=\left(1-\rho_{S}\right)\left(1-\rho_{P}\right)$ and $\underline{\pi}_{S}$ and $\underline{\pi}_{P}$ are defined by Equation (16) and Equation (17) respectively. The three terms on the right-hand side of Expression (26) represent total debt payments in distressed state under the three renegotiation strategies potentially adopted by the shareholder. The first branch represents the payoff from negotiating with both creditors (given by Expression (20)), the second branch represents negotiating with the parent creditor only (given by Expression (24)), and the third branch represents negotiating with the subsidiary creditor only (given by Expression (25)). As can be seen from inspecting Expression (26) creditor bargaining power and liquidation value are substitute means of extracting surplus from the shareholder in debt renegotiations. The intuition for substitutability is that the shareholder can never capture any part of the liquidation value, $\ell$ during the renegotiation process. Thus, the liquidation value ring-fences part of the firm's distressed state cash flows. This reduces the effect of bargaining power on the final division of distressed state cash flows. When the shareholder negotiates with both creditors, the total liquidation value, in similar fashion limits the scope for renegotiation and thus limits the effect of creditors' rights on the final distribution of cash flows. In fact, if we set the liquidation value to equal going-concern value, $x^{\mathrm{D}}-c$, then there would be no scope for the shareholder to capture cash flows through bargaining.

All three renegotiation strategies produce the same total ex post cash flow to creditors and the shareholder. Therefore, the scheme that minimizes total payments to creditors maximizes the shareholder's ex post payoff. Next note that it is apparent from Expression (26) that $C^{D}$ satisfies the conditions of Definition 1. This fact is recorded in the following lemma.

Lemma 1. $C^{D}$ is regular, i.e., it satisfies conditions I, II, and III of Definition 1.

Proof. See the Appendix.

\subsection{Optimal ex post exploitation of renegotiation options}

If a claim is renegotiated, the renegotiated payment will depend on the strength of creditor rights and the surplus available for division between the shareholder and the creditors. The liquidation value of a creditor's claim is always a lower bound on the payment that the creditor can receive. Thus, negotiations determine the fraction of unsecured debt payments - promised debt payments in excess of liquidation value - that the creditor will have to concede. This fraction will be determined by the strength of creditor rights. If a claim is not renegotiated, the shareholder will simply pay the claim's face value. Thus, the gain from renegotiating a claim will depend positively on the face value of the claim and negatively on the claim's liquidation value and the strength of creditor rights. Hence, although weaker creditor protection ceteris paribus makes renegotiation more attractive to the shareholder, it is not the only factor determining the shareholder's renegotiation strategy. A larger and/or less secured claim protected by stronger creditor right may be targeted for renegotiation even though a smaller and/or better secured claim subject to a weaker creditor rights regime is not.

The relative importance of claim size and creditor rights in determining the set of claims targeted for renegotiation critically depends on going-concern value, $x^{\mathrm{D}}$. As $x^{\mathrm{D}}$ increases, the cost of stronger creditor

rights to the shareholder increases. Thus, as $x^{\mathrm{D}}$ increases, it becomes more and more likely that the creditorrights effect will dominate the size-of-claim effect. Proposition 2 formalizes these observations.

\section{Proposition 2.}

$i$. The likelihood of renegotiating a creditor's claim is decreasing in the level of that creditor's rights, $\rho$. 
ii. The likelihood of renegotiating a creditor's claim is increasing in the initial face value of that creditor's claim.

iii. The likelihood of renegotiating a creditor's claim is decreasing in the liquidation value of that creditor's claim, $\underline{\pi}$.

$i v$. The larger the going-concern value, $x^{D}$, (a) the more likely that renegotiation will occur only under the weaker creditor rights regime, (b) the less likely that renegotiation will occur only under the stronger creditor rights regime, (c) the less likely that both claims will be renegotiated.

Proof. Follows directly from inspecting Expression (26).

\subsubsection{When parent and subsidiary operate under the same legal regime}

When the parent and subsidiary operate under the same legal regime, that is, when both are domiciled in the same country, then $\rho_{P}=\rho_{S}$. In this important special case, the analysis is simplified because the ability of creditors to extract going-concern value in renegotiations is the same. Thus, the shareholder's relative preference for negotiating claims at the parent and subsidiary levels is independent of operating cash flow and depends only on the relative level of unsecured debt issued to parent and subsidiary creditors. This observation is sufficient to characterize ex post renegotiation strategies in the case where subsidiaries and parents operate under the same legal regime.

Proposition 3. If the parent and subsidiary operate under the same legal regime, then the optimal ex post renegotiation strategy always involves renegotiating the claim with the largest promised claim net of liquidation value, that is,

i. If $k_{P}>k_{S}-\ell$, then the shareholder will always renegotiate the claim of creditor $P$.

ii. If $k_{P}<k_{S}-\ell$, then the shareholder will always renegotiate the claim of creditor $S$.

iii. If $k_{P}=k_{S}-\ell$ the shareholder is indifferent between the strategies of negotiating only with creditor $P$ and only with creditor $S$.

Proof. First note that we have shown that (a) it is not possible to fund the project entirely with secured debt and (b) subsidiary debt has effective priority. These two observations imply that

$$
k_{S}-\underline{\pi}_{S}>k_{P}-\underline{\pi}_{P} \text { if and only if } k_{S}-\ell<k_{P} .
$$

The rest of the proof follows directly from inspecting Expression (26) after imposing the restriction that $\rho_{S}=\rho_{P}$.

\subsubsection{Graphical analysis}

The results of Section 4.2, are illustrated in Figure 2. In this figure we depict the ex post value of the three negotiation strategies as a function of going-concern value, $x^{\mathrm{D}}$. Here we contrast the optimal renegotiation strategies when subsidiary and parent operate under a common legal regime (Panel B) with the two alternative cases: the case where creditor $P$ has stronger creditor rights (Panel A) and the case where creditor $S$ has stronger creditor rights (Panel C). Consistent with Proposition 3, in the equal creditor rights case of Panel B, one creditor is targeted for renegotiation over the entire range of going-concern values. For the parameters chosen for Panel B, that creditor is the parent creditor. In contrast, in Panels A and C, no single 
creditor is targeted for renegotiation over the entire parameter range. In Panel A, where the parent creditor has stronger creditor rights, the shareholder moves from a policy of renegotiating both parent and subsidiary debt at low going-concern value to a policy of renegotiating only subsidiary debt at high going-concern value. Renegotiating only parent debt is optimal for intermediate values. In Panel C, where the parent creditor has weaker creditor rights, the shareholder moves from a policy of renegotiating both parent and subsidiary debt at low going-concern value to a policy of renegotiating only parent debt at high going-concern value. Renegotiating only subsidiary debt is optimal for intermediate values.

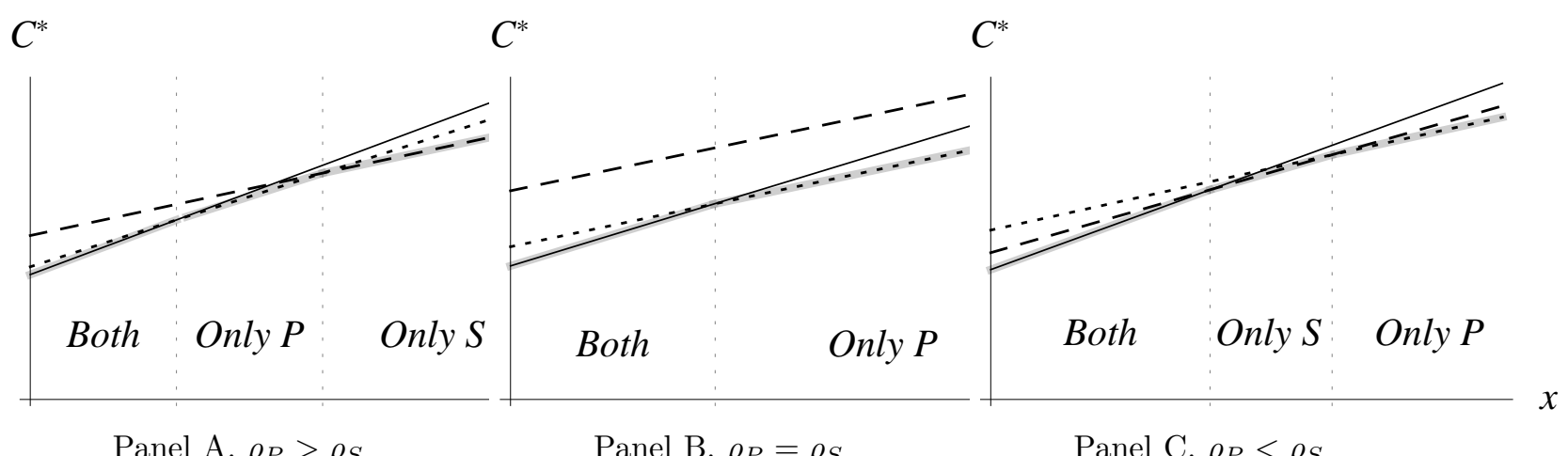

Figure 2: Debt payments and negotiation strategies. In the figure, the horizontal axis represents the goingconcern value of the firm and the vertical axis represents total debt payments. The dashed line represents total debt payments if only the subsidiary's debt is renegotiated; the dotted line represents total debt payments if only the parent's debt is renegotiated; the solid line represents total debt payments if both parent and subsidiary claims are renegotiated; the thick gray line represents the lower envelop of these three lines, that is, the payment under the shareholder's optimal ex post renegotiation strategy. The regions of going-concern value over which a given renegotiation strategy is optimal are indicated by the vertical guidelines.

\section{Optimal parent/subsidiary capital structure}

In this section, we determine the optimal mix between parent and subsidiary debt. In Section 3 we showed that, ex ante, when determining the initial parent/subsidiary debt mix, the shareholder will aim to maximize payments to creditors in the financially distressed state for any fixed total promised debt payment. In Section 4 we showed that, ex post, after receiving funding for the project, the shareholder will aim to exploit the optionality generated by the parent/subsidiary structure to minimize payments to creditors in the distressed state. Further, we show that the tension between the shareholder's ex ante and ex post incentives ensures that optimal parent-subsidiary debt mix minimizes the shareholder's ex post ability to use the optionality generated by the parent/subsidiary structure to lower payments to the creditors. The optimal mix between parent and subsidiary debt is affected by the liquidation value of assets and bargaining power of parent and subsidiary creditors, but the optimal mix is never extreme and always features some borrowing at both the parent and the subsidiary level.

Given Proposition 1 and Lemma 1, we see that a necessary and sufficient condition for $\left(k_{S}, k_{P}\right)$ to be an optimal mix of parent and subsidiary debt for a given level of total promised debt payments, $k$, is that $\left(k_{S}, k_{P}\right)$ maximize $C^{D}\left(k_{P}, k_{S}\right)$ over all $k_{S}$ and $k_{P}$ such that $k_{S}+k_{P}=k$.

Lemma 2. The optimal parent-subsidiary mix for a given level of total promised debt payments, $k$, maximizes 
total debt payments in distress, $C^{D}$ given $k$. These payments equal

$$
\min \left[\begin{array}{l}
\eta^{*}\left(\rho_{S}, \rho_{P}\right) \ell+\left(1-\eta^{*}\left(\rho_{S}, \rho_{P}\right)\right)\left(x^{D}-c\right), \\
\phi^{*}\left(\rho_{S}, \rho_{P}\right) \frac{1}{2}(\ell+k)+\left(\left(1-\phi^{*}\left(\rho_{S}, \rho_{P}\right)\right)\left(x^{D}-c\right)\right.
\end{array}\right],
$$

where $\eta^{*}$ and $\phi^{*}$ are weighting functions varying between 0 and 1 . These functions are dependent on creditor rights in the two legal regimes and are explicitly defined as follows:

$$
\begin{aligned}
\eta^{*}\left(\rho_{S}, \rho_{P}\right) & =\left(1-\rho_{S}\right)\left(1-\rho_{P}\right), \\
\phi^{*}\left(\rho_{S}, \rho_{P}\right) & =\frac{\left(1-\rho_{S}\right)\left(1-\rho_{P}\right)}{\frac{1}{2}\left(\left(1-\rho_{S}\right)+\left(1-\rho_{P}\right)\right)} .
\end{aligned}
$$

Proof. See the Appendix.

To understand Lemma 2, first note that the first term in the minimum expression defining total debt payments represents payments when the shareholder decides to renegotiate both claims; the second term in the minimum expression represents the payments when the shareholder renegotiates only one of the contracts. Because optimal policies call for minimizing the value of the switching option, this payment must be the same regardless of which creditor's claim is renegotiated. Both branches of the minimization function represent weighted averages. The weight of the smaller term in the average is given by either $\phi^{*}$ or $\eta^{*}$. Because both $\phi^{*}$ and $\eta^{*}$ are decreasing in creditor rights, this monotonicity implies, not surprisingly, that total debt payments are always increasing in creditor rights. Perhaps less obvious is that, for fixed average creditor rights, total debt payments are increasing in the divergence between creditor rights under the parent and subsidiary legal regimes. These insights are formally stated in Proposition 4 below.

Proposition 4. For any given initial distribution of creditor rights,

i. Increasing the creditor rights, $\rho$, of either creditor, while holding other creditor's rights fixed, increases total debt payments in the distressed state, $C^{D}$.

ii. Moreover, uniformity in creditors' rights leads to lower total debt payments than extreme allocations of rights: Consider debt payments under two creditor rights allocations, $\left(\rho_{S}^{\prime}, \rho_{P}^{\prime}\right)$ and $\left(\rho_{S}^{\prime \prime}, \rho_{P}^{\prime \prime}\right)$, such that $\rho_{S}^{\prime}+\rho_{P}^{\prime}=\rho_{S}^{\prime \prime}+\rho_{P}^{\prime \prime}$. Let $C^{D^{\prime}}$ and $C^{D^{\prime \prime}}$ represent the total debt payments produced by the two allocations. Then, $C^{D^{\prime}}>C^{D^{\prime \prime}} \Longleftrightarrow\left|\rho_{P}^{\prime}-\rho_{S}^{\prime}\right|>\left|\rho_{P}^{\prime \prime}-\rho_{S}^{\prime \prime}\right|$.

Proof. It follows from inspection of the creditor-payoff function $C^{D}$ given in Lemma 2.

Next, consider the optimal financial policies. These policies maximize $C^{D}$ for a given level of total promised debt payments, $k$. Define

$$
\bar{\rho}=\frac{1}{2}\left(\rho_{S}+\rho_{P}\right) .
$$

$\bar{\rho}$ represents the average creditor rights of the subsidiary and parent creditors. Also define

$$
L^{o}=\frac{\frac{1}{2}(k-\ell)}{x^{\mathrm{D}}-c-\ell} .
$$

$L^{o}$ equals one-half of the ratio between the total unsecured promised debt payments $k-\ell$ and the gain from reorganization, $x^{\mathrm{D}}-c-\ell$; thus, $L^{o}$ can be thought of as a measure of total debt burden relative to reorganization value. We formally define the optimal financial policies in Proposition 5 below.

Proposition 5. The set of optimal debt allocations between the parent and the subsidiary is characterized as follows: 
i. If average creditor rights are low relative to the total debt burden, i.e., $\bar{\rho}<L^{o}$, then the optimal parentsubsidiary debt mix is not unique and equals all convex combinations of the following two mixes:

$$
\begin{aligned}
& \left(k_{S}^{+}, k_{P}^{+}\right)=\left(k-\rho_{P}\left(x^{D}-c-\ell\right), \rho_{P}\left(x^{D}-c-\ell\right)\right), \\
& \left(k_{S}^{-}, k_{P}^{-}\right)=\left(\ell+\rho_{S}\left(x^{D}-c-\ell\right), k-\left(\ell+\rho_{S}\left(x^{D}-c-\ell\right)\right)\right) .
\end{aligned}
$$

ii. If the total debt burden is low relative to average creditor rights, i.e., $\bar{\rho} \geq L^{o}$, then there exists a unique optimal mix of parent and subsidiary debt given by

$$
k_{S}^{*}=\frac{\left(1-\rho_{S}\right) k+\left(\rho_{S}-\rho_{P}\right)\left(x^{D}-c\right)+\left(1-\rho_{S}\right) \ell}{\left(1-\rho_{S}\right)+\left(1-\rho_{P}\right)}, \quad k_{P}^{*}=k-k_{S}^{*} .
$$

Proof. See the Appendix.

Proposition 5 confirms that the set of optimal policies is usually fairly large. When the average level of creditor rights is low relative to the debt burden; i.e., when condition (i) of Proposition 5 holds, both claims are renegotiated over a large range of subsidiary-parent debt allocations. Only highly unbalanced ex ante allocations of debt will dissuade the shareholder from renegotiating both claims ex post. Although such unbalanced allocations would lead to renegotiation of only one contract, they would lead to even lower ex post payments to creditors. Thus, the ex ante optimal policy will induce the shareholder to renegotiate ex post with both the subsidiary and the parent creditors. Figure 3 depicts the implications of Proposition 5 for different ranges of parameter values. The figure shows that, when both claims are renegotiated, the set of optimal policies consists of a line segment with endpoints $k^{-}$and $k^{+}$. In the other case, that is, when condition (ii) of Proposition 5 holds, renegotiation is less attractive to the shareholder because the debt burden is smaller and/or creditor rights are stronger. Here, balanced allocations exist which lead to the renegotiation of only one claim. Thus, the ex ante payment maximizing policy leads to the renegotiation of only one claim and the optimal capital structure policy consists of a single point.

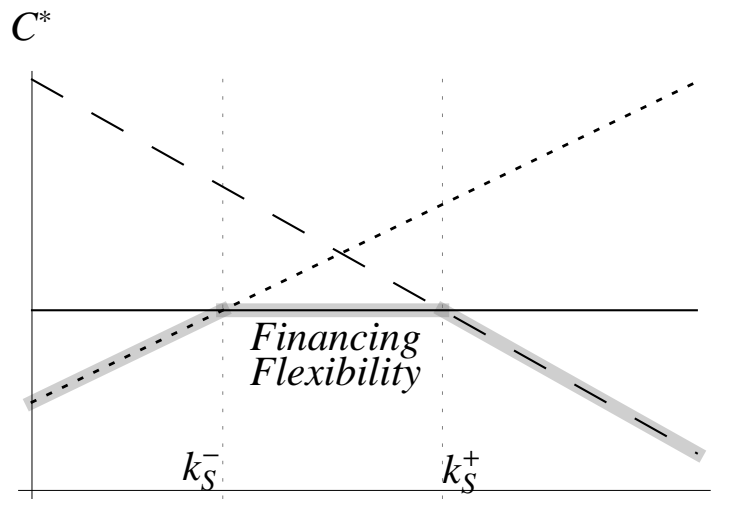

Panel A. Weak creditor rights

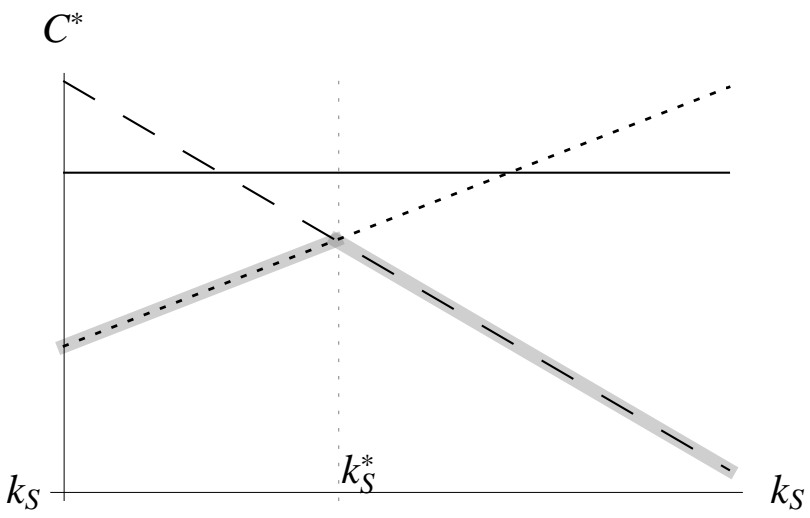

Panel B. Strong creditor rights

Figure 3: Debt payments and the parent-subsidiary debt mix. This figure depicts the optimal capital structure when the parent-subsidiary organization operates under disparate legal regimes. The horizontal axis in each figure represents the promised debt payment to creditor $S, k_{S}$. Total face value of the debt issued, $k$ is fixed. The vertical axis in each figure represents the total debt payment in the distressed state. The dotted lines represent the total payments to creditors in the event only creditor $P$ 's claim is renegotiated; the dashed lines represent the total payments to creditors in the event only creditor $S$ 's claim is renegotiated; the solid lines represent the total creditor payment when both creditors claims are renegotiated. The minimum total debt payment is represented by a thick gray line. In Panel A, the average of creditor rights, $\bar{\rho}=0.6$, is strictly less than the average rights in Panel $\mathrm{B}, \bar{\rho}=0.75$. As shown in Panel A, when creditor rights are relatively weak, the set of optimal policies, $\left(k^{-}, k^{+}\right)$is fairly large. At the higher level of $\bar{\rho}$ as depicted in Panel B, an unique optimal policy represented by $k_{S}^{*}$ exists. 
Next, we turn to the comparative statics of the optimal solution. We show that the firm's utilization of a capital market is proportional to the strength of creditor rights in that market, but a more creditor-friendly market will not be the sole financing venue. ${ }^{12}$ In contrast to the effect of changing creditor rights in a specific venue, the effect of increasing average creditor rights, $\bar{\rho}$, or going-concern value of the firm, $x^{\mathrm{D}}$, is not to push the interval of optimal policies up or down but rather to shrink the size of the interval, reducing the flexibility of the parent-subsidiary debt allocation. Proposition 6 formalizes these observations.

Proposition 6. The optimal financing policies are characterized by the following:

i. All optimal ratios between subsidiary and total debt are interior. That is, $k_{S} /\left(k_{S}+k_{P}\right) \in(0,1)$.

ii. The face value of creditor $S$ 's claim is increasing (decreasing) in creditor $S$ 's ( $P$ 's) rights. Similarly, the face value of creditor $P$ 's claim is increasing (decreasing) in creditor $P$ 's ( $S$ 's) rights.

iii. As average creditor rights, $\bar{\rho}$, increases, financing flexibility decreases; that is, the length of the interval $\left[k_{S}^{-}, k_{S}^{+}\right]$shrinks.

iv. As the going-concern value, $x^{D}$, increases, financing flexibility decreases.

$v$. The optimal level of debt issued to each creditor exceeds the claim's liquidation value.

Proof. See the Appendix.

The intuition behind Proposition 6 is straightforward: When designing its capital structure, the shareholder is attempting to maximize total debt payments. Given that a creditor's marginal ability to capture value is positively related to that creditor's rights and inversely related to the size of the creditor's claim, increasing a creditor's rights raises the marginal value of that creditor's claim in extracting payments from the shareholder and thus increases the degree to which the shareholder will rely on that creditor when formulating the initial financing mix. Increasing creditor rights on average, in contrast, does not lead to an increased relative preference for parent or subsidiary financing. Rather, it makes renegotiating both claims less attractive ex post and thus shrinks the size of the interval of debt allocations under which renegotiating both claims is ex post optimal.

\section{$5.1 \quad$ Numerical example}

In this section we develop a numerical illustration of the suboptimality of extreme parent/subsidiary debt mixes. For simplicity, assume that the liquidation value of assets is 0 . Also, suppose that creditor bargaining power is given by $\rho_{S}=\rho_{P}=\rho=2 / 3$; cash flows in the distressed and nondistressed states are given by $x^{\mathrm{D}}=120$, and $x^{\mathrm{ND}}=320$; the ex post cost of effort is given by $c=30$; ex ante effort parameter's value is given by $\gamma=230$; the project requires an investment of $I=116.80$. Equation (12) reveals that the first-best effort level, $e^{\mathrm{fb}}$, i.e., the firm-value maximizing effort level, is 1 . Because capital markets are competitive, the ex ante values of the creditors' claims are fixed by their participation constraints and thus are constant over effort levels. Hence, the agency costs of deviations from first-best effort are borne entirely by the shareholder. Thus, any ex ante shareholder financing policy that produces a larger deviation from first-best effort than another feasible policy cannot be optimal.

Suppose that the total face value of debt is given by $k^{*}=126$. Given this total face value, using Proposition 5 , we can find the optimal mix between parent and subsidiary debt. Plugging our parameters into Equation (27) reveals that $L_{o}=7 / 10$. Because $L_{o}>\bar{\rho}=2 / 3$, part (i) of this proposition describes the optimal debt mix.

\footnotetext{
${ }^{12}$ Because the set of optimal allocations in some cases is an interval rather than a single point, we must define what it means for an interval to increase. We choose a simple, natural definition: An interval increases in a parameter if both of its end points weakly increase when the parameter increases. This definition is a simple special case of the induced set ordering defined in Milgrom and Shannon [1994] and Topkis [1998].
} 
Proposition 5 part (i) reveals that there is a range of optimal mixes given by all convex combinations of $\left(k_{S}^{+}, k_{P}^{+}\right)=(66,60)$ and $\left(k_{S}^{-}, k_{P}^{-}\right)=(60,66)$. The midpoint of this range is the "balanced" parent/subsidiary debt mix $k_{P}^{*}=63, k_{S}^{*}=63$. Lemma 2 shows that, under this balanced policy, total payments to creditors in the distressed state, $C^{D}\left(k_{S}^{*}, k_{P}^{*}\right)$, equal 66 and thus the shortfall in the distressed state, $S^{\mathrm{D}}\left(k_{S}^{*}, k_{P}^{*}\right)=$ $k^{*}-C^{D}\left(k_{S}^{*}, k_{P}^{*}\right)$, is 46 .

The ex ante effort-incentive-compatibility condition, Equation (9), reveals that, under this balanced borrowing policy, the ex ante optimal effort level, $e^{*}$ is given by

$$
e^{*}=\frac{x^{\mathrm{ND}}-\left(x^{\mathrm{D}}-c\right)-S^{\mathrm{D}}\left(k_{S}^{*}, k_{P}^{*}\right)}{\gamma}=\frac{320-(120-30)-46}{230}=0.80 .
$$

Given this effort level, the expected value of the debt is given by

$$
e^{*} C^{\mathrm{ND}}\left(k_{S}^{*}, k_{P}^{*}\right)+\left(1-e^{*}\right) C^{D}\left(k_{S}^{*}, k_{P}^{*}\right)=e^{*}\left(k_{S}^{*}+k_{P}^{*}\right)+\left(1-e^{*}\right) 80=116.8 .
$$

Because this value equals $I$, the funds required to finance the investment, the creditor participation constraint, Equation (8), is satisfied. Thus, $\left(e^{*}=0.80, k_{S}^{*}=63, k_{P}^{*}=63\right)$ is an optimal ex ante policy.

Suppose that, instead of choosing the balanced policy, the shareholder opted for an "unbalanced" policy and issued only parent-level debt with face value equal to the face value of all debt issued under the balanced policy, i.e., the shareholder picked the mix $k_{S}^{u}=0, k_{P}^{u}=126$. In this case, Expression (26) shows that the total payments to creditors in the distress state, $C^{D}\left(k_{S}^{u}, k_{P}^{u}\right)$, equal 60 ; thus, the shortfall, $k^{*}-C^{D}\left(k_{S}^{u}, k_{P}^{u}\right)$, equals 66. Optimal effort, given by Equation (9), under unbalanced policy is

$$
e^{u}=\frac{x^{\mathrm{ND}}-\left(x^{\mathrm{D}}-c\right)-S^{\mathrm{D}}\left(k_{S}^{u}, k_{P}^{u}\right)}{\gamma}=\frac{320-(120-30)-66}{230}=82 / 115 \approx 0.713 .
$$

Given this effort level, the expected value of the debt is given by

$$
e^{*} C^{\mathrm{ND}}\left(k_{S}^{u}, k_{P}^{u}\right)+\left(1-e^{u}\right) C^{D}\left(k_{S}^{u}, k_{P}^{u}\right)=e^{u}\left(k_{S}^{u}+k_{P}^{u}\right)+\left(1-e^{u}\right) 60 \approx 107.061 .
$$

Thus, the value of the creditor's debt is less than the required investment and, hence, the unbalanced policy fails to satisfy the creditor-participation constraint, Equation (8). Thus, if the shareholder finances using an unbalanced policy of borrowing only at the parent level, the shareholder must increase the total face value of debt above $k^{*}=126$. Because $C^{D}$ is regular (Lemma 1), $C^{D}$ has property III of Definition 1 . Thus, increasing the total face value of debt increases the shortfall in the distressed state. Equation (9) shows that increasing the shortfall increases the deviation of the shareholder's effort from first-best effort. Thus, these unbalanced policies cannot be optimal.

\section{Extension: uncertain distressed state cash flow}

In our baseline model, cash flows are completely determined by the financial state of the firm, distressed or nondistressed. For the purposes of outlining the basic trade-offs involved in allocating debt across a parent-subsidiary organization, this approach is adequate. However, the fact that cash flows are certain in the distressed state has the unfortunate consequence of making the model unsuitable for making empirical predictions about the probability of renegotiation of parent vs. subsidiary debt. Since the optimal capital structure equates marginal enforceability across the parent and subsidiary legal regimes, the firm is indifferent between approaching the parent or subsidiary creditor when renegotiating only one of its debt contract. If 
distressed state cash flows were uncertain, the shareholder would not be able to choose an ex ante capital structure that exactly equates marginal enforceability across all financial states and thus, for some realized cash flows, shareholders would have a preference for the parent or subsidiary legal regime when renegotiating debt claims. In which case, empirical predictions regarding the choice of creditor for contract renegotiation could be developed.

In order to develop such empirical predictions, here we extend our analysis to permit cash flows to be uncertain even after conditioning on the financial state of the firm. As in the baseline model, no ex post effort is required in the nondistressed state. Thus, adding uncertainty to the nondistressed cash flows would not affect our results in an interesting way. So, we maintain the assumption that in the nondistressed state cash flows are known. However, we assume that cash flows in the distressed state can take values in the interval $\left[\underline{x}^{D}, \bar{x}^{D}\right]$. We assume that for all cash flows in this interval, the assumptions of the baseline model, given by Expression (1), are satisfied, i.e.,

$$
\ell<\underline{x}^{D}-c<\bar{x}^{D}-c<k<x^{\mathrm{ND}}
$$

We also assume that the cash flows in the distressed state is revealed at date 0 . Thus, bargaining will proceed at date 0 in exactly the same fashion as in the baseline model with the realized cash flow $x$ replacing $x^{\mathrm{D}}$ in all of the expressions. Thus, the actual payment to creditors will be defined by Expression (26) with $x$ replacing $x^{\mathrm{D}}$. However, the ex ante problem will be different because at date -2 , when capital structure is fixed creditors will not know the realization of $x$. Thus, we will need to note the dependence of $C^{D}$ on $x$, the realized cash flow. As in the baseline model, optimal parent-subsidiary debt mixes will be characterized as those mixes that maximize creditor payoffs for a fixed total promised debt payment. However, these payoffs will not be determined by taking expectations over all possible realizations of $x$. We assume that creditors and the shareholder, at date -2 , have a common prior over the interval of possible cash flow realizations when distress occurs, $\left[\underline{x}^{D}, \bar{x}^{D}\right]$ and that this prior is given by the absolutely continuous probability distribution function, $G$. Hence, all optimal financial policies solve the problem defined below:

$$
\begin{array}{ll}
\max _{k_{P} \geq 0, k_{S} \geq 0} & \mathcal{C}\left(k_{S}, k_{P}\right) ; \\
& k_{S}+k_{P}=k,
\end{array}
$$

where

$$
\mathcal{C}\left(k_{S}, k_{P}\right)=\int C^{D}\left(k_{S}, k_{P}, x\right) G(d x)
$$

and $C^{D}$ is defined by Expression (26) with $x \in\left[\underline{x}^{D}, \bar{x}^{D}\right]$ replacing $x^{\mathrm{D}}$. The key to solving the general optimization problem with uncertain cash flows is to compute the going-concern value, $x$, that leads to the exercise of each of the three renegotiation options. The computations are straightforward but a bit tedious. The relation between the cutoff values and the renegotiation regime depends on whether creditor rights are stronger under the subsidiary or parent legal regime. As we have seen in Section 4.2, when rights are stronger under the parent regime (i.e., $\rho_{P}>\rho_{S}$ ), then the shareholder's optimal renegotiation strategy for low going-concern values is to renegotiate both parent and subsidiary debt, while at very high going-concern values the optimal strategy is to renegotiate only subsidiary debt, with perhaps an intermediate range of values over which renegotiating parent debt only is optimal. In the opposite case, $\rho_{P}<\rho_{S}$, the pattern of renegotiation is somewhat different: As before, low going-concern values again lead to the renegotiation of both contracts. However, in contrast to the $\rho_{P}>\rho_{S}$ case, for very high going-concern values, parent debt is renegotiated while intermediate values may lead to renegotiation of subsidiary debt only. It is quite simple to solve or model for both of these cases. However, this process requires doubling the number of expressions but adds no new insight. Thus, in this section and the following sections we will assume that the first case 
holds, or that $\rho_{P}>\rho_{S}$. Using this assumption and performing the algebra required to find the values which equate creditor payments under each pair of possible renegotiation strategies yields the following expressions:

$$
\begin{aligned}
& x_{b p}\left(k_{S}, k_{P}\right)=c+\frac{1}{\rho_{S}} k_{S}-\frac{1-\rho_{S}}{\rho_{S}} \ell ; \\
& x_{b s}\left(k_{S}, k_{P}\right)=c+\frac{1}{\rho_{P}}\left(k_{P}+\ell\right)-\frac{1-\rho_{P}}{\rho_{P}} \ell ; \\
& x_{s p}\left(k_{S}, k_{P}\right)=c+\frac{\left(1-\rho_{S}\right)+\left(1-\rho_{P}\right)}{\rho_{P}-\rho_{S}} k_{S}+\frac{1-\rho_{S}}{\rho_{P}-\rho_{S}}\left(k_{P}+k_{S}+\ell\right) .
\end{aligned}
$$

$x_{b p}\left(k_{S}, k_{P}\right)$ represents the going-concern value at which renegotiating with both creditors produces the same total debt payoffs as renegotiating only with creditor $P$. Similarly, $x_{b s}\left(k_{S}, k_{P}\right)$ represents the going-concern value at which renegotiating with both creditors produces the same total debt payoffs as renegotiating only with creditor $S . x_{s p}\left(k_{S}, k_{P}\right)$ represents the going-concern value at which renegotiating only with creditor $S$ produces the same total debt payoffs as renegotiating only with creditor $P$. If the shareholder negotiates with both creditors, the slope of the creditor's payoff in $x$ is steepest. Ex post, the shareholder minimizes total debt payments. Thus, if it is optimal at going-concern value $x$ to renegotiate both claims, it must also be optimal to do so for all going-concern values lower than $x$. Thus, it is optimal to renegotiate at going-concern value $x$ if and only if $x \leq x_{b p}$ and $x \leq x_{b s}$, that is, $x \leq \min \left[x_{b p}, x_{b s}\right]$. Our assumption that $\rho_{P}>\rho_{S}$ implies that the slope of the creditor's payoff in $x$ is flattest if the shareholder negotiates only with creditor $S$. Applying the same logic, we see that the set of going-concern values at which it is optimal to renegotiate only with creditor $S$ exists if and only if $x \geq \max \left[x_{b s}, x_{s p}\right]$. If it is not optimal to renegotiate with both creditors or with creditor $S$ only, then it must be optimal to renegotiate with creditor $P$. These observations permit a simple description of the regions over which the different renegotiation patterns are optimal:

$$
\begin{aligned}
\hat{a}\left(k_{S}, k_{P}\right) & =\max \left[\min \left[x_{b p}\left(k_{S}, k_{P}\right), x_{b s}\left(k_{S}, k_{P}\right)\right], \underline{x}\right] \\
\hat{b}\left(k_{S}, k_{P}\right) & =\min \left[\max \left[x_{b s}\left(k_{S}, k_{P}\right), x_{s p}\left(k_{S}, k_{P}\right)\right], \bar{x}\right] .
\end{aligned}
$$

Note that if $x<\hat{a}$, then both creditors' claims will be renegotiated; if $x \in(\hat{a}, \hat{b})$, then only creditor $P$ 's claim will be renegotiated; if $x>\hat{b}$, then only creditor $S$ 's claim will be renegotiated. Using Equation (35), we can write the expected total debt payments in the event of financial distress as follows:

$$
\begin{aligned}
& \mathcal{C}^{D}\left(k_{S}, k_{P}\right)=\int_{\underline{x}}^{\hat{a}\left(k_{S}, k_{P}\right)}\left(\eta\left(\rho_{S}, \rho_{P}\right) \ell+\left(1-\eta\left(\rho_{S}, \rho_{P}\right)\right)(x-c)\right) G(d x) \\
& +\int_{\hat{a}\left(k_{S}, k_{P}\right)}^{\hat{b}\left(k_{S}, k_{P}\right)}\left(k_{S}\left(1-\rho_{P}\right)+\rho_{P}(x-c)\right) G(d x) \\
& +\int_{\hat{b}\left(k_{S}, k_{P}\right)}^{\bar{x}}\left(k_{P}\left(1-\rho_{S}\right)+\rho_{S}(x-c)+\left(1-\rho_{S}\right) \ell\right) G(d x) .
\end{aligned}
$$

Using this definition and basic optimization theory, we can provide the following characterization of the optimal financial policy design under uncertain cash flows. This is formally stated in Lemma 3 below.

Lemma 3. Optimal financial policies exist; these policies always feature a positive level of both subsidiary and parent-level debt. A policy $\left(k_{S}^{*}, k_{P}^{*}\right)$ is optimal if and only if it satisfies the condition

$$
\left(1-\rho_{P}\right)\left(G\left(\hat{b}\left(k_{S}^{*}, k_{P}^{*}\right)\right)-G\left(\hat{a}\left(k_{S}^{*}, k_{P}^{*}\right)\right)\right)-\left(1-\rho_{S}\right)\left(1-G\left(\hat{b}\left(k_{S}^{*}, k_{P}^{*}\right)\right)\right)=0 .
$$

Proof. See the Appendix. 
The tradeoff behind the first-order condition in Lemma 3 is that an increased reliance on creditor $S$ 's debt, $k_{S}$, increases the total debt payment for all cash flow levels in the interval $(\hat{a}, \hat{b})$ over which the shareholder renegotiates only with creditor $P$. At the same time, increasing creditor $S$ 's debt lowers the promised payments to creditor $P$ and lowers actual debt payment in the high cash flow states (i.e., states where $x>\hat{b}$ ) over which the shareholder negotiates only with creditor $S$. The marginal costs of these two effects are equated by the adjustments in the two intervals, $(\hat{a}, \hat{b})$ and $(\hat{b}, \bar{x})$, induced by changing the capital structure mix. Increasing subsidiary debt decreases the interval $(\hat{a}, \hat{b})$ and increases the interval $(\hat{b}, \bar{x})$. Similarly, decreasing subsidiary debt increases the interval $(\hat{a}, \hat{b})$ and decreases the interval $(\hat{b}, \bar{x})$. Thus, at some intermediate point, the marginal benefits associated with the two intervals are equalized.

The interesting comparative static issue raised by introducing differences in the creditors' rights and cash flow uncertainty regards how the magnitude of distressed state affects the shareholder's renegotiation strategy. When distressed state cash flows are known as in the baseline model, the shareholder sets capital structure in a fashion that eliminates the option value of choosing between creditor $S$ 's and creditor $P$ 's capital markets. In this case, it is not possible to make any deterministic prediction as to which market will be the most likely venue for renegotiation. Once uncertainty is introduced, it is no longer possible to equate value, so that for any given realization of going-concern value, the shareholder will usually have a strict preference for one of the two venues. The term $G(\hat{b})-G(\hat{a})$ represents the probability that the shareholder will opt to negotiate only with creditor $P$ and $1-G(\hat{b})$ represents the likelihood that the shareholder will opt to renegotiate only with creditor $S$. Rearranging the first-order condition given in Lemma 3 yields the following result.

Proposition 7. Given an optimal mix of subsidiary and parent-level debt, $\left(k_{S}^{*}, k_{P}^{*}\right)$, the odds ratio for ex post renegotiation at parent level versus subsidiary level, which is represented by

$$
\frac{G\left(\hat{b}\left(k_{S}^{*}, k_{P}^{*}\right)\right)-G\left(\hat{a}\left(k_{S}^{*}, k_{P}^{*}\right)\right)}{1-G\left(\hat{b}\left(k_{S}^{*}, k_{P}^{*}\right)\right)}
$$

equals $\left(1-\rho_{S}\right) /\left(1-\rho_{P}\right)$, that is,

$i$. the odds of a parent level vs. subsidiary level renegotiation equals the ratio between parent and subsidiary creditors' bargaining power, and

ii. claims issued under the legal regime which grants creditors the strongest rights are most likely to be renegotiated and thus have the highest default risk.

Note that the optimal capital structure involves a mix between issuing debt under the stronger and weaker creditor rights regimes. The mix is tilted toward the legal regime with stronger creditor rights but is nevertheless always a mix. Also note that it is clearly possible for the level of debt to be higher at the subsidiary than the parent level even when creditor rights are weaker at the subsidiary level. This result will tend to occur when liquidation value is high. Yet even in this case, renegotiation is more likely to occur under the stronger creditor rights regime. This follows even though, ceteris paribus, the debtor prefers to negotiate under the weaker regime. Because debt allocations are endogenous in our model, everything else is not held equal, the shareholder raises most unsecured (but not necessarily the most) debt where creditor protection is strongest. Thus, when renegotiation is required, it typically occurs under the strong creditor rights regime. For this reason, for parent-subsidiary organizations that can freely allocate debt across its component entities, it will not necessarily be the case that the debt they issue under weak creditor rights regimes will have a lower default spread than debt they issue under strong creditor rights regimes. On the one hand, restructuring that occur under the strong creditor rights regimes will be more favorable to creditors, leading to lower default spreads. On the other hand, restructuring will occur more often under strong creditor right regimes, leading to higher default spreads. 


\section{Robustness of the baseline model}

\subsection{Parent debt claims on the subsidiary}

In the baseline model, the parent firm's claim on subsidiary cash flow derived from its ownership of the subsidiary's equity. What effect would introducing parent debt claims on the subsidiary have on our results? In our model the only difference between debt and equity claims is priority in liquidation. Although liquidation is avoided in equilibrium, changes in liquidation value can affect the bargaining positions of creditors and thus the payments they are able to extract from the shareholder.

A parent firm debt claim that was subordinated to the debt claim of outside holders of subsidiary debt would have no effect on our analysis. This follows because a subordinated claim on subsidiary cash flows would have the same priority relative to subsidiary debt as the equity-based claim assumed in the baseline model. Thus, the interesting question is whether senior debt claims held by the parent would change any of the result in our analysis. Senior parent debt increases the marginal enforceability of the parent debt. As shown earlier, the shareholder aims to equate the marginal enforceability of parent and subsidiary debt, and marginal enforceability is decreasing in the face value of debt. Thus, as the size of the parent debt claim on the subsidiary increases, the optimal mix between parent and subsidiary debt counters this increase in enforceability of the parent debt claim by increasing the level of parent debt (decreasing its marginal enforceability) and reducing the level of subsidiary debt (increasing its marginal enforceability). In fact, the shift in the optimal levels of parent and subsidiary debt in response to an increase in senior parent debt in the subsidiary is one-to-one and leaves the creditor repayment in the distressed state under the optimal capital structure policy, $C^{D}$, unchanged. Thus, parent debt claims have no material effect on our results. ${ }^{13}$

\subsection{Same creditor holds both claims: Unified claim ownership}

Modifying our model by assuming that the same creditor held both claims, would have no essential effect on our results. There are two reasons for the irrelevance of unified ownership - one relating to the general characteristic of our solution and the other to the specifics of our bargaining model. The general reason is that our bargaining solution is efficient. In equilibrium, ex post efficiency is attained and the first-best ex post decision - renegotiate debt claims to ensure first best effort - always emerges from distress negotiations. Thus, unified ownership cannot improve the efficiency of bargaining. Because almost all bargaining models of renegotiation under symmetric information predict ex post efficiency, the lack of any efficiency gain from unified claim ownership would hold in almost any reasonable bargaining framework. However, in the case of our bargaining model, not only would efficiency be unaffected by unified claim ownership, the distribution of value produced by renegotiation would also be unaffected. The irrelevance of unified ownership for distribution of value results from a feature of our bargaining model - the creditors only make final take-itor-leave-it offers. Thus, whenever creditors make offers, they know that they have all the bargaining power in negotiations. Creditor demands are only constrained by the fact that, in order to reach the position of making final offers, they must risk dissipation. Thus, if, in the first negotiation, the creditor reaches the final offer stage, the creditor will never be in a better position to extract surplus from the shareholder. Hence, the creditor will use the final offer to extract the maximum surplus regardless of any other claims might be negotiated in the second negotiation, even his own claim. Therefore, the behavior of a unified owner will be the same as the behavior of creditor who owns only a single (subsidiary or parent) claim.

\footnotetext{
${ }^{13}$ For the details of this argument see Appendix $\mathrm{C}$ of the working paper version of this manuscript
} 


\subsection{Simultaneous offers}

Our assumption of sequential negotiations raises one important question: whether the sequential negotiation assumption is responsible for the value-relevance of the parent subsidiary debt mix. That is, if offers were made simultaneously to both creditors, would parent subsidiary structure still affect total creditor payoffs? Simultaneous offers do not render the parent-subsidiary debt mix irrelevant. ${ }^{14}$ If the shareholder makes a simultaneous offer to both creditors specifying a renegotiated face value for both claims, the balancing incentives derived in this paper would still be present. The essential reason for the robustness of our result is that, because the parent and subsidiary are legally distinct entities, there is no mechanism (e.g., a bankruptcy system that aggregates parent and subsidiary claims) to block creditors from rejecting simultaneous offers and forcing the shareholder into 1-1 negotiations. This exit option affects the shareholder's initial simultaneous offer and the value of the exit option depends on the face value of the creditor's claim. Thus, the incentive to balance the marginal enforceability of creditor claims persists.

\subsection{Relaxing the assumption that rejected final offers lead to dissipation}

In our baseline model, if the shareholder rejects a creditor's final offer, value in excess of liquidation value is dissipated. Thus, if a shareholder rejects the final offer of one creditor, he does not have the option of simply exiting negotiations with that creditor and approaching the other creditor and attempting to strike a deal. Any model that grants creditor some bargaining power would have to feature some probability of dissipation if the creditor's final offer is rejected. However, a perfectly reasonable alternative model formulation might specify that a rejected final offer triggers dissipation with some probability and with a complementary probability simply leaves the shareholder free to approach the other creditor. In such a framework, the number of potential offers and counteroffers is infinite and thus modeling negotiations is much more complex. Since our aim is to model the effect of renegotiation options on capital structure rather than develop new models of claim renegotiation, we have eschewed this formulation. However, assuming attention is restricted to stationary equilibria, it is not hard to see that permitting an exit option would reduce creditor bargaining power. Claim enforceability would still be decreasing in claim size and the incentive of firms to choose interior mixes between parent and subsidiary debt would be maintained. Since the results of our analysis do not depend on the overall level of creditor bargaining power, the conclusions reached in the immensely more complex framework would be qualitatively the same as those reached in our much simpler framework.

\subsection{Face-value constrained bargaining}

Our model of debt renegotiation follows Hart and Moore [1994] by assuming that renegotiation requires repudiation of the original debt contract. We choose this framework for modeling renegotiations because, it is the standard formulation of debt renegotiation (e.g., Harris and Raviv [1995], Harris and Raviv [1990], Aghion et al. [1992], Bolton and Scharfstein [1996], and Shleifer and Vishny [1992]). Had we chosen a different formulation, it would have raised a legitimate concern over whether conclusions regarding the effect of parent/subsidiary structures on capital structure were not produced by parent/subsidiary structure but rather by our non-standard model of debt renegotiations. A consequence of the Hart-Moore formulation is that renegotiation, because it involves repudiation, strips the renegotiating shareholder of the protections provided by the debt contract. This permits the creditor to demand more than the face value of its claim

\footnotetext{
${ }^{14}$ See Appendix D of the working paper version of this paper for a more detailed discussion of this point
} 
in post-repudiation negotiations. Of course, repudiation is the shareholder's choice and thus he will eschew repudiation when such creditor demands are credible. However, the fact that the creditor can sometimes make credible demands in excess of face value will deter renegotiation in some cases.

Thus, a perfectly reasonable question to ask with respect to our analysis is whether a framework which permitted the shareholder to renegotiate without repudiation would yield different results from our analysis. The basic effect of renegotiation without repudiation is that creditor final offers would be restricted to being less than the face value of debt. Imposing the face value constraint on debt renegotiations greatly complicates the analysis and, in fact, renegotiation strategies for the shareholder are quite different under the face-value constraint. However, just as in the baseline model, minimization of the value of these ex post renegotiation options through ex ante choice of debt mix, leads to interior optimal debt mixes between parent and subsidiary debt. ${ }^{15}$

\section{Conclusion}

We develop a model of the financing policy of parent-subsidiary organizations. The analysis shows that parent-subsidiary organizations will attempt to minimize the overall credit spread on their debt by equating the marginal enforceability of debt claims in different capital markets. The diminishing marginal enforceability of claims leads to internal optimal mixes between subsidiary borrowing and borrowing at the parent level. The exact mix of financing chosen depends on the relative strength of creditor rights in the parent and subsidiary legal regimes, the going-concern versus liquidation value, the total external financing requirements of the firm, and the distribution of going-concern value. Testable comparative statics are then derived which link parent-subsidiary capital structure and debt renegotiation strategy to these variables.

\section{References}

P. Aghion, O. Hart, and J. Moore. The economics of bankruptcy reform. National Bureau of Economic Research Working Paper \#4097, 1992.

H. V. Almeida and D. Wolfenzon. A theory of pyramidal ownership and family business groups. The Journal of Finance, 61(6):2637-2680, 2006.

L. Bebchuk. The rent protection theory of corporate ownership and control. National Bureau of Economic Research Working Paper \#7203, 1999.

P. Bolton and D. S. Scharfstein. Optimal debt structure and the number of creditors. Journal of Political Economy, 104(1):1-25, 1996.

B. Chowdhry and J. Coval. Internal financing of MNC subsidiaries: Debt vs. equity. Journal of Corporate Finance, 4(1):87-106, 1998.

B. Chowdhry and V. Nanda. Financing of multinational subsidiaries: Parent debt vs. external debt. Journal of Corporate Finance, 1(2):259-281, 1994.

S. Davydenko and J. Franks. Do bankruptcy codes matter? A study of defaults in France, Germany, and the U.K. The Journal of Finance, 63(2):565-607, 2008.

\footnotetext{
${ }^{15} \mathrm{~A}$ detailed development of these ideas is presented in Appendix $\mathrm{E}$ of the working paper version of this manuscript.
} 
M. Desai, C. Foley, and J. Hines Jr. A MNC perspective on capital structure choice and internal capital markets. Journal of Finance, 59(6):2451-2488, 2004.

J. Fuentes and C. Maqueria. Determinants of loan repayment in Chile. Universidad de Chile working paper, 1999.

A. Goel, V. Nanda, and M. Narayanan. Career concerns and resource allocation in conglomerates. Review of Financial Studies, 17(1):99-128, 2004.

M. Harris and A. Raviv. Capital structure and the informational role of debt. The Journal of Finance, 45 (2):321-349, 1990 .

M. Harris and A. Raviv. The role of games in security design. Review of Financial Studies, 8(2):327-367, 1995.

O. Hart and B. Holmstrom. Theory of Contracts. Cambridge University Press, 1987.

O. Hart and J. Moore. A theory of debt based on the inalienability of human capital. The Quarterly Journal of Economics, 109(4):841-879, 1994.

H. Huizinga, L. Laevenb, and G. Nicodeme. Capital structure and international debt shifting. Journal of Financial Economics, 88(1):80-118, 2008.

K. John, L. W. Senbet, and A. K. Sundaram. Cross-border liability of multinational enterprises, border taxes, and capital structure. Financial Management, 20(4):54-67, 1991.

C. Kahn and A. Winton. Moral hazard and optimal subsidiary structure for financial institutions. The Journal of Finance, 59(6):2531-2575, 2002.

A. Kolasinski. Subsidiary debt, capital structure, and internal capital markets. Journal of Financial Economics, 94(2):327-343, 2009.

R. La Porta, F. Lopez-de Silanes, A. Shleifer, and R. Vishny. Corporate ownership around the world. Journal of Finance, 54(2):471-517, 1999.

J. Lee. On the financial efficiency and control in business groups. University of Florida Working Paper, 2010.

H. E. Leland. Corporate debt value, bond covenants, and optimal capital structure. The Journal of Finance, 49(4):1213-1252, 1994.

L. M. LoPucki. The death of liability. The Yale Law Journal, 106(1):1-92, 1996.

V. Maksimovic and G. Phillips. Do conglomerate firms allocate resources inefficiently across industries? Theory and evidence. The Journal of Finance, 57(2):721-767, 2002.

P. Milgrom and C. Shannon. Monotone comparative statics. Econometrica, 62(1):157-180, 1994.

M. Osborne and A. Rubinstein. Bargaining and Markets. Academic Press, New York, 1990.

O. Ozbas. Integration, organizational processes, and allocation of resources. Journal of Financial Economics, 75(1):201-242, 2005.

D. S. Scharfstein. The dark side of internal capital markets II: Evidence from diversified conglomerates. National Bureau of Economics Research Working Paper \#6532, 1998.

A. Shleifer and R. Vishny. Liquidation values and debt capacity: A market equilibrium approach. The Journal of Finance, 47(4):1343-1366, 1992. 
P. Stumpp, W. Rottino, D. Fanger, R. Stephan, and D. Carter. Rating non-guaranteed subsidiaries: Credit considerations in assigning subsidiary ratings in the absence of legally binding parent support. Moody's Rating Methodology, 1-12, 2003.

D. Topkis. Supermodularity and Complementarity. Princeton University Press, Princeton, NJ, 1998. 


\section{Appendix: Proofs of results}

Proof of Proposition 1. The proof of Proposition 1 follows directly from the following two lemmas.

Lemma 8.1. Suppose that the function $C^{D}$ (which relates promised creditor payments to actual creditor payments in the distressed state) is regular. If $\left(e^{\prime}, k_{S}^{\prime}, k_{P}^{\prime}\right)$ is a feasible optimal policy for the shareholder and thus satisfies the creditor participation condition, (8), and the incentive compatibility condition, (9), and there exists another policy $\left(k_{S}^{o}, k_{P}^{o}\right)$ producing the same total promised payments, i.e., $k_{S}^{o}+k_{P}^{o}=k_{S}^{\prime}+k_{P}^{\prime}$ and under which the actual payments to creditors in the distress state are higher, i.e., $C^{D}\left(k_{S}^{o}, k_{P}^{o}\right)>C^{D}\left(k_{S}^{\prime}, k_{P}^{\prime}\right)$, then policy $\left(e^{\prime}, k_{S}^{\prime}, k_{P}^{\prime}\right)$ is not an optimal ex ante policy for the shareholder. Thus, no ex ante policy can be optimal unless it maximizes payments to creditors in the distress state over all policies producing the same level of total promised payments.

Proof. Using the definition, $k=k_{S}+k_{P}$, and expressions (7), (8), and (9), we can express the shareholder's date -2 problem as follows:

$$
\begin{aligned}
& \underset{e \in[0,1], k_{P} \geq 0, k_{S} \geq 0}{\operatorname{Max}}\left(x^{\mathrm{ND}}-\left(k_{S}+k_{P}\right)\right) e+\left(x^{\mathrm{D}}-c-\left(k_{S}+k_{P}-S^{*}\left(k_{P}, k_{S}\right)\right)\right)(1-e)-\frac{\gamma}{2} e^{2} \\
& \text { subject to: } \\
& \mathrm{CP}: \quad\left(k_{S}+k_{P}\right) e+\left(k_{S}+k_{P}-S^{*}\left(k_{P}, k_{S}\right)\right)(1-e) \geq I, \\
& \mathrm{IC}: \quad e=\frac{x^{\mathrm{ND}}-\left(x^{\mathrm{D}}-c\right)-S^{*}\left(k_{S}, k_{P}\right)}{\gamma} .
\end{aligned}
$$

Assume that $\left(e^{\prime}, k_{S}^{\prime}, k_{P}^{\prime}\right)$ is feasible and thus satisfies the feasibility conditions, IC and CP, of Problem 38 . These conditions imply that

$$
\begin{aligned}
\left(k_{S}^{\prime}+k_{P}^{\prime}\right) e^{\prime}+\left(k_{S}^{\prime}+k_{P}^{\prime}-S^{*}\left(k_{P}^{\prime}, k_{S}^{\prime}\right)\right)\left(1-e^{\prime}\right) & \geq I \\
e^{\prime} & =\frac{x^{\mathrm{ND}}-\left(x^{\mathrm{D}}-c\right)-S^{*}\left(k_{S}^{\prime}, k_{P}^{\prime}\right)}{\gamma} .
\end{aligned}
$$

Let $\bar{\Pi}^{\prime}$ represent the shareholder's payoff under $\left(e^{\prime}, k_{S}^{\prime}, k_{P}^{\prime}\right)$. Then

$$
\bar{\Pi}^{\prime}=\left(x^{\mathrm{ND}}-\left(k_{S}^{\prime}+k_{P}^{\prime}\right)\right) e^{\prime}+\left(x^{\mathrm{D}}-c-\left(k_{S}^{\prime}+k_{P}^{\prime}-S^{*}\left(k_{P}^{\prime}, k_{S}^{\prime}\right)\right)\right)\left(1-e^{\prime}\right)-\frac{\gamma}{2} e^{2}
$$

Note that expression (39) implies that

$$
\bar{\Pi}^{\prime} \leq x^{\mathrm{ND}} e^{\prime}+\left(x^{\mathrm{D}}-c\right)\left(1-e^{\prime}\right)-I-\frac{\gamma}{2} e^{\prime 2}
$$

Now consider the parent-subsidiary capital structure $\operatorname{mix}\left(k_{S}^{o}, k_{P}^{o}\right)$. Let $e^{o}$ be the incentive compatible (IC) effort level under $\left(k_{S}^{o}, k_{P}^{o}\right)$, i.e.,

$$
e^{o}=\frac{x^{\mathrm{ND}}-\left(x^{\mathrm{D}}-c\right)-S^{*}\left(k_{S}^{o}, k_{P}^{o}\right)}{\gamma} .
$$

Then, by the hypothesis of the proposition that $C^{D}\left(k_{S}^{o}, k_{P}^{o}\right)>C^{D}\left(k_{S}^{\prime}, k_{P}^{\prime}\right)$ and $k_{S}^{o}+k_{P}^{o}=k_{S}^{\prime}+k_{P}^{\prime}$, the definition of a shortfall implies that $S^{*}\left(k_{S}^{o}, k_{P}^{o}\right)<S^{*}\left(k_{S}^{\prime}, k_{P}^{\prime}\right)$. The IC condition of Problem 38 thus implies that $e^{o}>e^{\prime}$. Because $S^{*}\left(k_{S}^{o}, k_{P}^{o}\right)<S^{*}\left(k_{S}^{\prime}, k_{P}^{\prime}\right), e^{o}>e^{\prime}$, and $k_{S}^{o}+k_{P}^{o}=k_{S}^{\prime}+k_{P}^{\prime}$, it must be the case that under $\left(e^{o}, k_{S}^{o}, k_{P}^{o}\right)$ the $\mathrm{CP}$ condition of Problem 38 is strictly satisfied, i.e.,

$$
\left(k_{S}^{o}+k_{P}^{o}\right) e^{o}+\left(k_{S}^{o}+k_{P}^{o}-S^{*}\left(k_{P}^{o}, k_{S}^{o}\right)\right)\left(1-e^{o}\right)>I .
$$


Consider capital structures of the form $\left(\alpha k_{S}^{o}, \alpha k_{P}^{o}\right)$ for $\alpha \in[0,1]$. Let $k^{o}(\alpha)=\alpha\left(k_{S}^{o}+k_{P}^{o}\right)$. Payments to creditor's in the distressed state are gven by $C^{o}(\alpha)=C^{D}\left(\alpha k_{S}^{o}, \alpha k_{P}^{o}\right)$. The shortfall under these polices is given by $S^{o}(\alpha)=k^{o}(\alpha)-C^{o}(\alpha)$. Let $e^{o}(\alpha)$ represents the incentive compatible level of effort under $\left(\alpha k_{S}^{o}, \alpha k_{P}^{o}\right)$, i.e.,

$$
e^{o}(\alpha)=\frac{x^{\mathrm{ND}}-\left(x^{\mathrm{D}}-c\right)-S^{o}(\alpha)}{\gamma} .
$$

Note that when $\alpha=1, e^{o}(\alpha)=e^{o}$ and $k^{o}(\alpha)=k_{S}^{o}+k_{P}^{o}$. Thus, inequality (43) implies that

$$
k^{o}(1) e^{o}(1)+\left(k^{o}(1)-S^{o}(1)\right)\left(1-e^{o}(1)\right)>I .
$$

Next, note that our assumption, given in expression (1), that $I>x^{\mathrm{D}}-c$ implies that, for some $\alpha^{\prime}<1$ such that $k^{o}\left(\alpha^{\prime}\right)<x^{\mathrm{D}}-c$, this implies by hypothesis I that $C^{D}<x^{\mathrm{D}}-c$ and thus

$$
k^{o}\left(\alpha^{\prime}\right) e^{o}\left(\alpha^{\prime}\right)+\left(k^{o}\left(\alpha^{\prime}\right)-S^{o}\left(\alpha^{\prime}\right)\right)\left(1-e^{o}\left(\alpha^{\prime}\right)\right)<I .
$$

$k^{o}(\alpha)$ is a continuous function of $\alpha$, by hypothesis $C^{D}$ is continuous thus, $S^{o}$ is continuous in $\alpha$. $e^{o}(\alpha)$ is also continuous in $\alpha$. Thus, the Intermediate Value Theorem shows that there exists $\alpha^{*}<1$ such that

$$
k^{o}\left(\alpha^{*}\right) e^{o}\left(\alpha^{*}\right)+\left(k^{o}\left(\alpha^{*}\right)-S^{o}\left(\alpha^{*}\right)\right)\left(1-e^{o}\left(\alpha^{*}\right)\right)=I .
$$

Equation (47), when substituted into shareholder's objective function in Problem 38, implies that the shareholder's payoff under $\left(e^{o}\left(\alpha^{*}\right), \alpha k_{S}^{\prime}, \alpha k_{P}^{\prime}\right)$, which we represent by $\bar{\Pi}^{o}$, is

$$
\bar{\Pi}^{*}=x^{\mathrm{ND}} e^{o}\left(\alpha^{*}\right)+\left(x^{\mathrm{D}}-c\right)\left(1-e^{o}\left(\alpha^{*}\right)\right)-I-\frac{\gamma}{2} e^{o}\left(\alpha^{*}\right)^{2} .
$$

Because $S^{o}(\alpha)$ is nondecreasing in $\alpha$ by hypothesis III and $\alpha^{*}<1$, thus $S^{o}\left(\alpha^{*}\right) \leq S^{o}(1)=S^{*}\left(k_{S}^{o}, k_{P}^{o}\right)$. We have already shown that $S^{*}\left(k_{S}^{o}, k_{P}^{o}\right)<S^{*}\left(k_{S}^{\prime}, k_{P}^{\prime}\right)$. Thus, $S^{o}(\alpha)<S^{*}\left(k_{S}^{\prime}, k_{P}^{\prime}\right)$. Thus, the IC condition of Problem 38 implies that

$$
e^{\prime}<e^{o}\left(\alpha^{*}\right)<\frac{x^{\mathrm{ND}}-\left(x^{\mathrm{D}}-c\right)}{\gamma} .
$$

Because the function $e \rightarrow x^{\mathrm{ND}} e+\left(x^{\mathrm{D}}-c\right)(1-e)-I-\frac{\gamma}{2} e^{2}$ is increasing for $e \leq\left(x^{\mathrm{ND}}-\left(x^{\mathrm{D}}-c\right)\right) / \gamma$, expression (49) implies, when applied to expressions (48) and (42) that, $\bar{\Pi}^{*}$, the shareholder's payoff under $\left(e^{o}\left(\alpha^{*}\right), \alpha k_{S}^{o}, \alpha k_{P}^{o}\right)$, is greater than $\bar{\Pi}^{\prime}$,the shareholder's payoff under $\left(e^{\prime}, k_{S}^{\prime}, k_{P}^{\prime}\right)$. Equations (44) and (47) show that $\left(e^{o}\left(\alpha^{*}\right), \alpha k_{S}^{o}, \alpha k_{P}^{o}\right)$ is a feasible solution to Problem 38. Thus, $\left(e^{\prime}, k_{S}^{\prime}, k_{P}^{\prime}\right)$ is not an optimal solution to Problem 38 because it produces a lower payoff to the shareholder than the feasible solution $\left(e^{o}\left(\alpha^{*}\right), \alpha^{*} k_{S}^{o}, \alpha^{*} k_{P}^{o}\right)$.

Lemma 8.2. Suppose that policy $\left(e^{*}, k_{S}^{*}, k_{P}^{*}\right)$ is an ex ante optimal policy for the shareholder. If $\left(e^{*}, k_{S}, k_{P}\right)$ is another policy producing the same total promised payments and the same actual payments in the event of distress, i.e., $k_{S}+k_{P}=k_{S}^{*}+k_{P}^{*}$ and $C^{D}\left(k_{S}, k_{P}\right)=C^{D}\left(k_{S}^{*}, k_{P}^{*}\right)$, then $\left(e^{*}, k_{S}, k_{P}\right)$ is also an ex ante optimal policy.

Proof. Because $k_{S}+k_{P}=k_{S}^{*}+k_{P}^{*}$ and $C^{D}\left(k_{S}, k_{P}\right)=C^{D}\left(k_{S}^{*}, k_{P}^{*}\right), S^{D}\left(k_{S}, k_{P}\right)=S^{D}\left(k_{S}^{*}, k_{P}^{*}\right)$. Thus, $\left(e^{*}, k_{S}, k_{P}\right)$ satisfies the effort incentive compatibility condition because $\left(e^{*}, k_{S}^{*}, k_{P}^{*}\right)$ does. $\left(e^{*}, k_{S}^{*}, k_{P}^{*}\right)$ and $\left(e^{*}, k_{S}, k_{P}\right)$ produce the same payoffs to creditors. Hence, $\left(e^{*}, k_{S}, k_{P}\right)$ satisfies the creditor participation constraint because $\left(e^{*}, k_{S}^{*}, k_{P}^{*}\right)$ does. Because, $\left(e^{*}, k_{S}^{*}, k_{P}^{*}\right)$ and $\left(e^{*}, k_{S}, k_{P}\right)$ produce the same payoff to the shareholder and $\left(e^{*}, k_{S}^{*}, k_{P}^{*}\right)$ is optimal, so is $\left(e^{*}, k_{S}, k_{P}\right)$.

Lemma 8.1 implies condition (i) of the proposition and Lemma 8.2 implies condition (ii). 
Proof of Lemma 1. Clearly $C^{D}\left(k_{S}, k_{P}\right) \leq k$ as can be seen by inspecting equation (26). Thus, condition I is satisfied. The continuity condition, condition II, is satisfied because $C^{D}$, as defined in equation (26), is the composition of continuous functions. Finally, to verify condition III, let $D^{+}(f)$ represent the right derivative of the function $f$. If $D^{+}$is subscripted by a variable, it represents the right derivative with respect to that variable; If $D^{+}$is subscripted by a number, $i$, it represents the right derivative with respect to the $i$ th argument of the function. Note that $C^{D}$ is concave and thus $S^{*}$ is convex as it is the sum of the convex functions $\left(k_{P}, k_{S}\right) \rightarrow k_{S}+k_{P}$ and $\left(k_{P}, k_{S}\right) \rightarrow-C^{D}\left(k_{P}, k_{S}\right)$. Thus, $\alpha \rightarrow S^{D}\left(\alpha k_{S}, \alpha k_{P}\right)$ is convex. A convex function is nondecreasing if and only if its right derivative is non-negative over the function's domain. Computing the right derivative yields

$$
D_{\alpha}^{+}\left(S^{D}\left(\alpha k_{S}, \alpha k_{P}\right)\right)=\left(k_{S}+k_{P}\right)-\left(k_{S} D_{1}^{+}\left(C^{D}\left(k_{S}, k_{P}\right)\right)+k_{P} D_{2}^{+}\left(C^{D}\left(k_{S}, k_{P}\right)\right)\right) .
$$

Inspecting equation (26) reveals that

$$
k_{S} D_{1}^{+}\left(C^{D}\left(k_{S}, k_{P}\right)\right)+k_{P} D_{2}^{+}\left(C^{D}\left(k_{S}, k_{P}\right)\right) \leq \max \left[\rho_{S}, \rho_{P}\right] \max \left[k_{S}, k_{P}\right]<k_{S}+k_{P} .
$$

Thus, condition III is satisfied.

Proof of Lemma 2. In order to maximize $C^{D}$ over all parent subsidiary debt structures, $\left(k_{S}, k_{P}\right)$ and satisfy the constraint that $k_{S}+k_{P}=k$, we use the constraint that $k_{S}+k_{P}=k$ so substitute out $k_{P}$, i.e, we set $k_{P}=k-k_{S}$. This yields the following simplified problem.

$$
\max _{k_{S}} C^{D}\left(k_{S}, k-k_{S}, x^{\mathrm{D}}\right) \quad \text { s.t. } k_{S} \in[0, k] .
$$

First we consider the optimal policy when $k_{S} \leq \ell$. If the subsidiary debt level is less than $\ell$, the subsidiary debt contract will never be renegotiated. This implies that the parent debt contract has to be renegotiated. Thus, the payoff to creditors will equal

$$
\left(1-\rho_{P}\right) k_{S}+\rho_{P}\left(x^{\mathrm{D}}-c\right)+\left(1-\rho_{P}\right) \underline{\pi}_{P}=\left(1-\rho_{P}\right) k_{S}+\rho_{P}\left(x^{\mathrm{D}}-c\right)+\left(1-\rho_{P}\right)\left(\ell-k_{S}\right) .
$$

This expression is constant in $k_{S}$ and equal to

$$
\rho_{P}\left(x^{\mathrm{D}}-c\right)+\left(1-\rho_{P}\right) \ell
$$

In contrast, for all levels of subsidiary debt slightly larger than $\ell$ but still small enough so that renegotiating only creditor $P$ is optimal, the payment to creditors is given by

$$
\left(1-\rho_{P}\right) k_{S}+\rho_{P}\left(x^{\mathrm{D}}-c\right) .
$$

Because $k_{S}>\ell$, expression (53) is larger than (52). Thus, we have shown that policies that involve subsidiary debt levels of less than $\ell$ do not maximize total debt payments. Next consider policies featuring subsidiary debt levels in excess of $\ell$. If $k_{S}>\ell$, and $k_{S}+k_{P}=k$, then the total debt payments, assuming parent debt only is renegotiated, which we represent by $R_{P}$, and subsidiary debt only is renegotiated, which we represent by $R_{S}$, are given as follows:

$$
\begin{aligned}
& R_{P}\left(k_{S}\right)=\left(1-\rho_{P}\right) k_{S}+\rho_{P}\left(x^{\mathrm{D}}-c\right), \\
& R_{S}\left(k_{S}\right)=\left(1-\rho_{S}\right)\left(k-k_{S}\right)+\rho_{S}\left(x^{\mathrm{D}}-c\right)+\left(1-\rho_{S}\right) \ell .
\end{aligned}
$$


As shown in (20), the payoff from renegotiating both claims, which we represent by $A$, is given by

$$
A=\eta\left(\rho_{S}, \rho_{P}\right) \ell+\left(1-\eta\left(\rho_{S}, \rho_{P}\right)\right)\left(x^{\mathrm{D}}-c\right) .
$$

Thus, the objective function $C^{D}$ takes the following form:

$$
\begin{aligned}
C^{D}\left(k_{S}, k-k_{S}\right) & =\min \left[A, f\left(k_{S}\right)\right], \\
f\left(k_{S}\right) & =\min \left[R_{S}\left(k_{S}\right), R_{P}\left(k_{S}\right)\right] .
\end{aligned}
$$

The above observation implies that the maximum payment to creditors is given by

$$
\max _{k_{S} \in[0, k]} \min \left[A, f\left(k_{S}\right)\right]
$$

Next, note that the maximum of $f$ over the feasible region must be attained at a point where $R_{S}\left(k_{S}\right)=$ $R_{P}\left(k_{S}\right)$. Otherwise, by pushing up the smaller component the $f$ can be increased. Thus, $f$ is maximized at

$$
\left(1-\rho_{P}\right) k_{S}+\rho_{P}\left(x^{\mathrm{D}}-c\right)=\left(1-\rho_{S}\right)\left(k-k_{S}\right)+\rho_{S}\left(x^{\mathrm{D}}-c\right)+\left(1-\rho_{S}\right) \ell .
$$

The solution to (59) is given by

$$
k_{S}^{\mathrm{eq}}=\frac{\left(1-\rho_{S}\right) k+\left(\rho_{S}-\rho_{P}\right)\left(x^{\mathrm{D}}-c\right)+\left(1-\rho_{S}\right) \ell}{\left(1-\rho_{S}\right)+\left(1-\rho_{P}\right)} .
$$

Because $A$ is a constant independent of the choice variables we have that $k_{S}^{e q}$ is a maximizer of total debt payments. Let $f^{*}$ equal the maximum of $f$, then a simple calculation shows that

$$
f^{*}=\max _{k_{S} \in[0, k]} f\left(k_{S}\right)=f\left(k_{S}^{\mathrm{eq}}\right)=\left(1-\phi^{*}\right)\left(x^{\mathrm{D}}-c\right)+\phi^{*} \frac{k+\ell}{2},
$$

where

$$
\phi^{*}=\frac{\left(1-\rho_{S}\right)\left(1-\rho_{P}\right)}{\frac{1}{2}\left(\left(1-\rho_{S}\right)+\left(1-\rho_{P}\right)\right)} .
$$

Equations (61) and (62) imply that the maximal total debt payment is given by

$$
\min \left[A, f^{*}\right]=\min \left[A,\left(1-\phi^{*}\right)\left(x^{\mathrm{D}}-c\right)+\phi^{*} \frac{k+\ell}{2}\right] .
$$

Proof of Proposition 5. A simple calculation shows that

$$
\bar{\rho}<\frac{\frac{1}{2}(k-\ell)}{x-c-\ell}
$$

holds, if and only if

$$
f^{*}=\min [f]>A .
$$

Optimal policies $k_{S}^{*}$ satisfy the condition that

$$
\min \left[f\left(k_{S}^{*}\right), A\right]=\min \left[f^{*}, A\right]
$$

(recall the definition of the function $f$ given by (57)). Thus, when (64) holds, optimal policies are all those 
policies $k_{S}^{*}$ satisfying the condition that $f\left(k_{S}^{*}\right) \geq A$. Algebra shows that these are the policies given by Proposition 5. This result establishes Part (i) of Proposition 5.

Next, consider Part (ii) of Proposition 5. If (64) does not hold, then (65) is not satisfied. In this case, we have that $f^{*}<A$. Optimal policies $k_{S}^{*}$ satisfy the condition that $\min \left[f\left(k_{S}\right), A\right]=\min \left[f^{*}, A\right]$. Thus, when condition (65) fails, optimal policies are all those policies $k_{S}^{*}$ satisfying the condition that $f\left(k_{S}\right)=f^{*}$. By the proof of Lemma 2, solutions to this problem are given by $\left(k_{S}^{*}, k_{P}^{*}\right)$ as defined in Proposition 5 .

Proof of Proposition 6. To prove Part (i), simply inspect the explicit solutions given in Proposition 5. Note that all solutions involve interior levels of subsidiary creditor financial policies. To prove Part (ii), note that the function $h\left(k_{P}, \rho_{S}, \rho_{P}\right):=C^{D}\left(k-k_{P}, k_{P}, x^{\mathrm{D}}\right)$ exhibits decreasing differences in $\rho_{S}$ and increasing differences in $\rho_{P}$; this implies that the set of optimizers of the function are decreasing in $\rho_{S}$ and increasing in $\rho_{P}$ in the induced set ordering. ${ }^{16}$

Because $k_{S}=k-k_{P}$, the opposite comparative statics hold for $k_{S}$. Parts (iii) and (iv) follow from considering the interval of optimal policies defined in Part (i) of Proposition (5) and noting that the left endpoint of the interval increases while the right end point decreases as $\rho$ or $x^{\mathrm{D}}$ increases. Finally, Part (v) follows from the first part of the proof of Lemma 2 which showed that for any optimal level of subsidiary debt, $k_{S}^{*}, k_{S}^{*}>\ell$. This implies, by expression (17) that the liquidation value of parent debt is zero and thus because parent debt is interior, its face value must exceed its liquidation value.

Proof of Lemma 3. Substitute into the problem the constraint that $k=k_{S}+k_{P}$ and note that the function $C^{D}$ is almost everywhere differentiable in $x$ and that $G$ is absolutely continuous, with a derivative in $k_{S}$ of $\left(1-\rho_{P}\right.$ ) over $[\hat{a}, \hat{b}]$ and $-\left(1-\rho_{S}\right)$ over $[\hat{b}, \bar{x}]$ (or use Leibniz's rule to explicitly differentiate $\mathcal{C}^{D}$ ). We see that the first-order condition for an optimal choice of $k_{S}$ is given by

$$
\frac{d \mathcal{C}^{\mathrm{D}}}{d k_{S}}=\left(1-\rho_{P}\right)\left(G\left(\hat{b}\left(k_{S}, k-k_{S}\right)\right)-G\left(\hat{a}\left(k_{S}, k-k_{S}\right)\right)\right)-\left(1-\rho_{S}\right)\left(1-G\left(\hat{b}\left(k_{S}, k-k_{S}\right)\right)\right)=0 .
$$

At $k_{S}=0$ the derivative is positive and at $k_{S}=k$ the derivative is negative; because the derivative is continuous, the first-order condition (67) must be satisfied at any maximum. Because $C^{D}$ is concave in the control variable $k_{S}$ for all $x$, and because expectations preserve concavity, $\mathcal{C}^{D}$ is concave. Thus, condition (67) is sufficient for an optimum. Hence, the proof.

\footnotetext{
${ }^{16}$ See, for example, Lemma 2.8.1 [Topkis, 1998].
} 